・研究报告・

\title{
中国西南干旱河谷植被的区系地理成分与空间分异
}

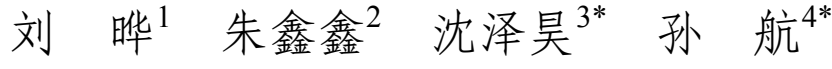 \\ 1 (北京大学深圳研究生院, 城市规划与设计学院, 深圳 518055) \\ 2 (信阳师范学院生命科学学院, 河南信阳 464000) \\ 3 (北京大学城市与环境学院生态学系, 地表过程分析与模拟教育部重点实验室, 北京 100871) \\ 4 (中国科学院昆明植物研究所生物多样性与生物地理学重点实验室, 昆明 650204)
}

\begin{abstract}
摘要: 根据对云南、四川、甘肃三省九条主要河流干旱河谷的植物群落调查数据, 对我国西南干旱河谷维管束植 物区系的科、属分布区类型进行划分, 并分析其地理分布格局。结果表明: (1)西南干旱河谷区的植物区系地理成 分复杂, 联系广泛, 共包含 11 个科级和 15 个属级分布区类型; 总体上, 科、属两级热带/温带成分比例分别为 3.06 和 1.77，显示了强烈的热带区系亲缘及温带区系的后期影响；与地中海-西亚至中亚植物区系存在一定联系; 其东亚 成分和中国特有成分比例低于亚热带区系平均水平，且中国-喜马拉雅成分比例高于中国-日本成分。(2)从西南向 东北方向, 植物区系的热带性质逐渐减弱, 温带性质逐渐增强; 科、属水平区系成分与古地中海-中亚区系的相似 性逐渐增强; 东亚和中国特有成分比例增加; 南盘江与元江的干旱河谷植物区系之间存在中国-日本和中国-喜马 拉雅成分的分界线。(3)根据干旱河谷植物属区系成分的比例构成将怒江、澜沧江和元江与其他流域分开，显示了 长江溯源侵蚀和水系合并对西南诸河流植物区系发育的影响。
\end{abstract}

关键词: 中国西南干旱河谷; 维管束植物; 区系成分；相似性；空间分异

\section{Flora compositions and spatial differentiations of vegetation in dry val- leys of Southwest China}

\author{
Ye Liu ${ }^{1}$, Xinxin Zhu' ${ }^{2}$ Zehao Shen ${ }^{3 *}$, Hang Sun $^{4 *}$ \\ 1 School of Urban Planning and Design, Shenzhen Graduate School, Peking University, Shenzhen 518055 \\ 2 College of Life Science, Xinyang Normal University, Xinyang, Henan 464000 \\ 3 Department of Ecology, College of Urban and Environmental Sciences, the Key Laboratory for Earth Surface Proc- \\ esses of the Ministry of Education, Peking University, Beijing 100871 \\ 4 Key Laboratory of Plant Diversity and Biogeography of East Asia, Kunming Institute of Botany, Chinese Academy of \\ Sciences, Kunming 650204
}

\begin{abstract}
Based on plant community data collected from dry valleys of nine major rivers in Gansu, Sichuan and Yunnan provinces of Southwest China, we divided the families and genera of the vascular plants into geographic elements of Chinese flora, and analyzed the spatial patterns. We found the flora of dry valleys of Southwest China revealed a complex composition of geographic elements with wide floristic connections, including 11 family area-types and 15 genera area-types. The ratio of tropical versus temperate floristic elements was 3.06 at the family level, and 1.77 at the genus level, showing a distinctive affinity for tropical floras, and later imprints of temperate floras. A clear floristic linkage existed between the dry valley floras and the Mediterranean, Western- and Central-Asian floras. The percentages of East Asian elements and endemic Chinese elements were below the average value in the flora found for the subtropical region in China. The Sino-Himalayan element had a value higher than that for the Sino-Japan element in the dry valley floras. The floristic affinity to the tropics weakened while affinity to temperate flora intensified moving in the region from the southwest to northeast. Linkages with the Mediterranean-Central Asian floras, and also the percentage of East Asian elements and endemic Chinese elements increased in the same direction. A boundary between the Sino-Japan type and Sino-Himalayan type was detected between the dry valley floras of Nanpan-
\end{abstract}

收稿日期: 2015-09-11; 接受日期: 2016-02-02

基金项目：国家自然科学基金(41371190)和交通运输部西部计划项目(2008 318799 17)

*共同通讯作者 Co-authors for correspondence. E-mail: shzh@urban.pku.edu.cn; hsun@mail.kib.ac.cn 
jiang River and Yuanjiang River. With respect to the genus level floristic composition of geographic elements, Nujiang River, Lancangjiang River and Yuanjiang River were separated from the other rivers, which are all upper branches of the Yangtze River. This departure indicated the impacts of the evolution of the Yangtze River, which were characterized by headward erosion, river confluences, on the characteristics of modern flora in dry valleys.

Key words: dry valleys of Southwest China; vascular plants; floristic elements; similarity; spatial differentiation

现代植物区系的空间结构是植物对区域环境, 尤其是气候条件长期适应的结果, 可以反映植物类 群的扩散、迁移和分布情况(王荷生, 1997), 对其进 行研究不仅有助于了解植物群落的特征、性质、起 源和分布(宋永昌, 2001), 还是植物群落分类、植被 分区和植物地理研究的基础, 并且可为制定生物多 样性保护对策、可持续地利用植物资源提供重要参 考(Vetaas \& Grytnes, 2002)。植物科的分布型可以反 映相对古老的区系联系，代表植物演化的区域共 性。植物属的分类特征相对稳定，同属种通常起源 相同、进化趋势类似，因此属的分布型可以反映更 加一致的演化历程和区系发育环境(彭华和吴征镒, 1997; 吴征镒等, 2011; 应俊生和陈梦玲, 2011)。

西南干旱河谷的植物区系具有特定的来源组 成，并且在独具特色的干旱河谷气候条件(杨勤业 和郑度, 1989)和相对封闭的河谷环境下经历了长期 的适应和演化过程(吴征镒和王荷生, 1983), 物种组 成具有很显著的特有性(金振洲, 2002)。其中干热河 谷以热带性质的科、属、种为主(金振洲和欧晓昆, 2000), 典型植被呈稀树草原外貌; 干暖河谷以热带 性质的科、属占优势, 发育了与地中海沿岸的马基 植被(Maquis)(河谷型马基植被)相似的外貌结构(张 荣祖, 1992; 金振洲和欧晓昆, 2000); 干温河谷植物 区系中温带成分的比例高于热带成分，同时掺杂较 多的高山(喜马拉雅)-北极成分(张荣祖, 1992)。

对我国西南地区干旱河谷的植物研究始于 20 世纪 50 年代; 80 年代后，《中国植被》、《四川植被》、 《云南植被》等先后总结了干旱河谷植被的类型、 结构及物种组成, 局部研究主要涉及植被、植物区 系以及古植物学等方面(朱华，1990; 曹永恒和金振 洲, 1993; 金振洲和欧晓昆, 2000; 孙航和李志敏, 2003; Zhang et al, 2011), 特别是金振洲等(1995)和 金振洲(2002)对川西和云南的干旱河谷植物区系地 理、植被分类和地理进行了系统总结。然而, 迄今 未见对我国西南各干旱河谷植物区系的汇总分析,
因此其整体特征、结构成分与地理分异还不清楚。

本文在对中国西南地区九大江河干旱河谷段 的植被进行全面群落学调查的基础上，进一步汇集 有关文献中的植物分布数据，首次对该区域干旱河 谷植物区系的科、属地理成分的组成、分布及各流 域之间的相关性进行分析、比较，探讨西南干旱河 谷植物区系的性质、组成特征和空间分化格局，以 期对其形成发育的背景、对外联系，包括各大河流 之间的关联有所反映。

\section{1 材料和方法}

\section{1 研究区域概况}

我国亚热带干旱河谷, 主要分布在横断山区范 围内的几条大江河流域，包括南盘江、元江、怒江、 澜沧江、金沙江、雅聋江、大渡河、岷江以及白龙 江等流域的局部河谷段(张荣祖, 1992; 包维楷和王 春明，2000；明庆忠，2006；邱祖青等，2007)，具有 独特的气候、地貌和植被组合特征。区域地势整体 北高南低、各条大江河谷底部的海拔也自北向南降 低。具有干旱气候的河谷段随河道走向不规则分布, 一般只是在河谷底至两侧山地的一定海拔范围内, 总面积较小 (金振洲和欧晓昆，2000; 金振洲, 2002)。总体上, 西南干旱河谷的温度高、年降雨量 低、蒸发量大，与垂直带的高海拔地区及同一纬度 东部地区的气候特征不同(张荣祖, 1992), 且不同河 谷气候也有较大差异(张荣祖, 1992; 金振洲, 1998, 1999)。其中，半湿润-半干旱河谷出现在西南纵向 岭谷区的南部边缘与东部，半干旱-干旱河谷出现 在滇西北与川西南的三江上段。

干热河谷植被普遍具有扭曲、变矮、叶变小、 革质、多毛或刺的形态特征，以适应干旱气候。“稀 树灌木草丛”以旱生禾草草丛为主构成大片草地植 被, 并散生稀疏的乔木和灌木, 并有少数的肉质多 刺灌从(金振洲和欧晓昆，2000; 刘晔等，2016)。干 暖河谷植被多为小叶、硬叶、多刺、疏生、矮生的 
灌从，常成半荒漠状外貌，有散生的耐旱乔木和硬 叶栎类灌从分布(金振洲和欧晓昆, 2000; 刘晔等, 2016)。干温河谷的主要植被类型为干旱小叶灌从, 以成从散生的阔叶灌从为主, 草本植物稀少(刘伦 辉, 1989; 张荣祖, 1992; 刘晔等, 2016)。

针对地质历史时期金沙江从石鼓被河流袭夺、 与元江分离这一历史事件(Barbour, 1936; 任美锷 等, 1959; Clark et al, 2004), 将金沙江流域干旱河谷 以石鼓为界, 分为金沙江上段和金沙江下段。

\section{2 样地设置与调查}

2009年7月至2013年8月, 分别对云南、四川、 甘肃境内的怒江、澜沧江、元江、南盘江、金沙江、 雅袭江、大渡河、怅江、白龙江流域的干旱河谷进 行野外样方调查, 共设置采样点 275 个, 调查了面 积 $100 \mathrm{~m}^{2}(10 \mathrm{~m} \times 10 \mathrm{~m})$ 的植被样方 993 个, 采样区 域基本覆盖了西南地区亚热带干旱河谷的分布范 围(图1)。

植被调查采样尽量选取人为干扰不明显的地 点。采样点总体上沿江设置, 样点之间的距离 $10 \mathrm{~km}$ 左右。根据生境条件在每个样点设置2-6个样方。 调查样方中草本、灌木的种类、多度、盖度, 以及 乔木的种类、胸径、株高。测量记录样方经纬度和 海拔信息, 以及坡度、坡向、坡位等环境因子。

在植被调查过程中, 野外采集植物标本 6,000 余份, 主要依据《中国植物志》、《云南植物志》和
《四川植物志》完成分类鉴定, 共记录 2,340 个物 种。为了充分反映干旱河谷植物区系的构成及其分 布状况, 本研究还收录已出版的云南和四川境内干 旱河谷植物区系的研究成果, 包括金振洲和欧晓昆 (2000)、金振洲(2002)、欧晓昆等(2006)及朱金金金金 (2014)中的数据, 最终参照《中国植物志》 (中国植 物志编辑委员会，1959-2004)统一拉丁名，建立物 种数据库。共包含分布于西南九大江河干旱河谷中 的186科1,016属2,794种维管束植物(表1)。

\section{3 数据处理}

\subsection{1 植物区系地理成分分析}

根据吴征镒等(2011)对世界和中国种子植物区 系地理成分的划分，以及《中国植物志第一卷》 (吴 征镒和陈心启, 2004)中对莿类和石松类植物区系组 成的划分, 对西南干旱河谷分布的维管束植物科、 属进行分布区类型划分 (附录 1 ); 参照沈泽吴和张 新时(2000), 将各分布区类型划分为世界分布成分、 热带成分、北方温带成分、古地中海成分和东亚成 分五大类, 分别在科、属水平上作进一步统计分析。

\subsection{2 植物区系地理成分相似性}

选择Jaccard指数 $\left(C_{j}\right)$ 比较不同流域干旱河谷植 物区系构成的相似性。计算公式是:

$$
C_{j}=c /(a+b-c)
$$

其中, $\mathrm{c}$ 表示两个样本共有的物种数, $\mathrm{a}$ 和 $\mathrm{b}$ 分别表示 样本 $\mathrm{A}$ 和样本 $\mathrm{B}$ 的物种数。 $C_{j}$ 的取值范围在 $0-1$, 值

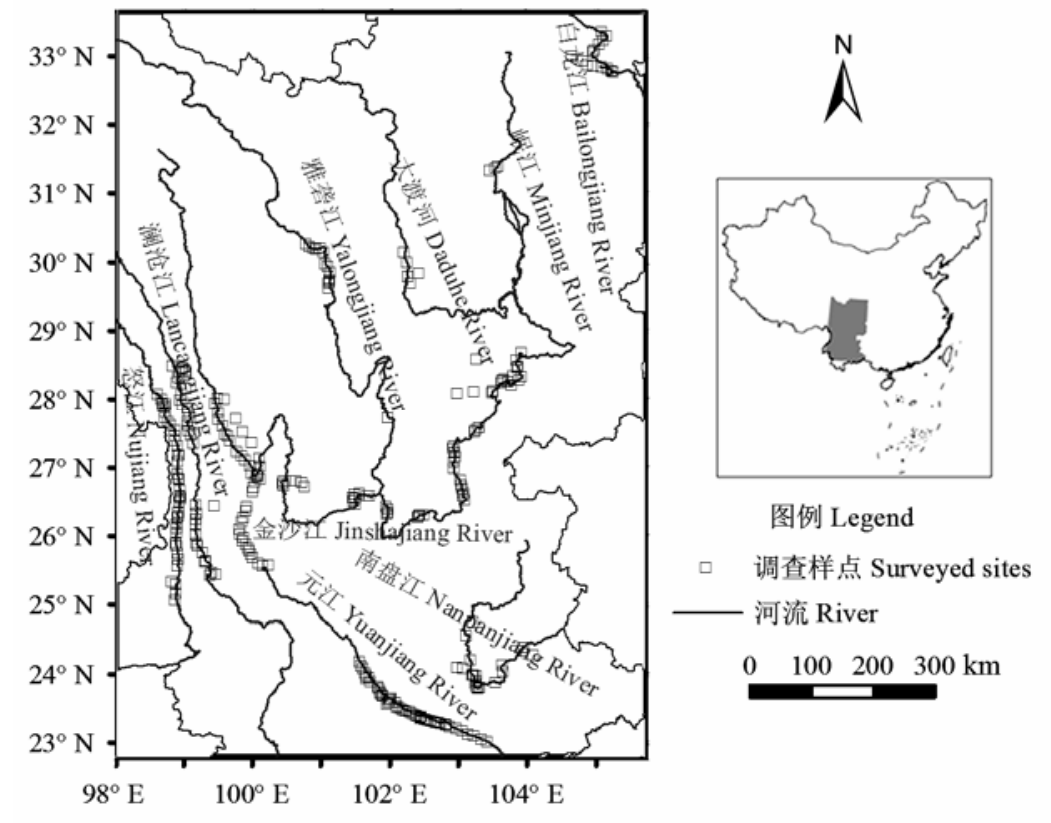

图1 西南九个流域干旱河谷的植物调 查采样点分布 (中国全图审图号 GS (2008)1157号)

Fig. 1 The distribution of sampling sites for the vegetation investigation in dry valleys of 9 rivers of Southwest China 
表1 中国西南各流域干旱河谷植被的样方分布

Table 1 The plot distribution of vascular plants in dry valleys of Southwest China

\begin{tabular}{lllll}
\hline 流域 & 样方数 & 海拔 & 东经 & 北纬 \\
Valley & Number of plots & Elevation $(\mathrm{m})$ & East longitude $\left({ }^{\circ}\right)$ & North latitude $\left({ }^{\circ}\right)$ \\
\hline 白龙江 Bailongjiang River & 136 & $762-1,016$ & $104.6-105.21$ & $32.76-33.35$ \\
大渡河 Daduhe River & 47 & $1,200-1,432$ & $102.17-102.38$ & $29.64-30.14$ \\
金沙江 Jinshajiang River & 563 & $358-3,298$ & $99.17-103.88$ & $25.56-28.69$ \\
澜沧江 Lancangjiang River & 129 & $1,010-4,297$ & $98.8-100.22$ & $24.82-28.48$ \\
怅江 Minjiang River & 24 & $1,710-2,270$ & $103.42-103.54$ & $31.33-31.4$ \\
南盘江 Nanpanjiang River & 38 & $952-1,787$ & $102.94-104.04$ & $23.78-24.74$ \\
怒江 Nujiang River & 385 & $680-1,999$ & $98.42-98.91$ & $24.65-28.07$ \\
雅聋江 Yalongjiang River & 62 & $1,236-2,736$ & $100.74-101.93$ & $27.73-30.27$ \\
元江 Yuanjiang River & 228 & $182-1,530$ & $100.43-103.38$ & $23.01-25.17$ \\
\hline
\end{tabular}

越大，相似性越高。

\section{2 结果}

\section{1 植物科属组成}

所记录的西南干旱河谷分布的维管束植物共 计 186 科 1,016 属 2,794 种, 包括蒝类和石松类植物 29 科56属165种、裸子植物4科12属20种、被子植物 153 科948属2,609种。其中, 种类最多的前四个科依次 为菊科、禾本科、蝶形花科、蓄微科, 共占总属数 的 $25.69 \%$, 总种数的 $26.38 \%$; 另外, 唇形科、毛茛 科、大戟科、茜草科也包含较多的种、属, 共占总 属数的 $8.66 \%$ 和总种数的 $11.20 \%$ 。有 15 个属的物种 数 $>15$, 分别为铁线莲属 (Clematis)、蒿属 (Artemisia)、悬钩子属(Rubus)、栒子属(Cotoneaster)、 大戟属(Euphorbia)、臺草属(Carex)、蓄薇属 $(R o s a) 、$ 柳属(Salix)、栎属(Quercus)、木蓝属(Indigofera)、 唐松草属 (Thalictrum) 、榕属 (Ficus)、苶属 (Polygonum)、薯预属(Dioscorea)、堇菜属(Viola), 占 总种数的 $11.48 \%$ 。总体上, 本区维管束植物优势科、 优势属明显, 另有 36 个单属单种科, 520 个单种属, 分别占本区总科数的 $19.35 \%$, 总属数的 $51.18 \%$, 反 映了西南干旱河谷地区相对古老和复杂的植物区 系组成。

不同流域由于干旱河谷的范围大小不同(表1), 科、属、种数差别较大(表2), 但菊科、蝶形花科、 禾本科在各河流区系中均为种类最多的科(表2)。

\section{2 植物区系地理成分构成}

\subsection{1 科的区系成分构成与分布}

记录的全部186科维管束植物属于 11 个分布区 类型, 29 科葓类和石松类植物属于 6 个分布区类型,
4 科裸子植物属于 2 个分布区类型， 153 科被子植物 属于 11 个分布区类型(表 3$)$ 。其中包括世界分布 58 科, 占总数的 $31.2 \%$ 。余下 128 科中不同地理成分占除世 界分布科外总科数的百分比从大到小分别为: 泛热 带分布 $(54.7 \%) 、$ 北温带分布 $(19.5 \%)$ 、东亚和热带 美洲间断分布 $(9.4 \%)$ 、东亚和北美洲间断分布 $(3.9 \%)$ 、热带亚洲至热带大洋洲分布 $(3.9 \%)$ 、旧世 界热带分布 $(3.1 \%)$ ，其他类型仅含1-2科。温带分布 (分布型8-10)合计 31 科，占除世界分布科外总科数 的 $24.2 \%$, 而热带分布(分布型2-7)有 95 科，占除世 界分布科外总科数的 $74.2 \%$, 近于前者 3 倍, 反映了 干旱河谷植物区系较强的热带亲缘。

各流域的科分布类型组成，均以泛热带分布为 主, 其次为北温带分布, 还有一定数量的东亚(热 带、亚热带)和热带美洲间断分布; 除主体的热带成 分和温带成分，大渡河、金沙江下段、澜沧江和怒 江还有东亚分布(表3)。

\subsection{2 属的植物区系成分构成与分布}

记录到的全部1,016属维管束植物属于中国植 物区系的全部 15 个分布区类型，56属烣类和石松类 植物属于 11 个分布区类型，12属裸子植物属于 6 个 分布区类型，948属被子植物属于 15 个分布区类型 (表4)。其中世界分布有 71 属, 占总属数的 $7.0 \%$ 。余 下945属中不同地理成分占除世界分布属外总属数 的百分比从大到小的顺序为: 泛热带分布 $(22.2 \%)$ 、 北温带分布 $(16.0 \%)$ 、热带亚洲(印度-马来西亚，太 平洋诸岛)分布 $(9.6 \%)$ 、旧世界热带分布 $(8.1 \%)$ 、旧 世界温带分布 $(7.6 \%)$ 、热带亚洲至热带大洋洲分布 (6.2\%)、东亚和北美洲间断分布 $(5.4 \%)$ 、热带亚洲 至热带非洲分布 $(5.0 \%)$ 、热带亚洲和热带美洲间断 
表2 中国西南各流域干旱河谷植被的主要维管束植物科组成

Table 2 The composition of dominant families of vascular plants in dry valleys of Southwest China

\begin{tabular}{|c|c|c|c|c|c|c|c|}
\hline \multirow{3}{*}{$\begin{array}{l}\text { 流域 } \\
\text { Valley }\end{array}$} & \multirow{3}{*}{$\begin{array}{l}\text { 科数 } \\
\text { Number } \\
\text { of } \\
\text { families }\end{array}$} & \multirow{3}{*}{$\begin{array}{l}\text { 属数 } \\
\text { Number } \\
\text { of } \\
\text { genera }\end{array}$} & \multirow{3}{*}{$\begin{array}{l}\text { 种数 } \\
\text { Number } \\
\text { of } \\
\text { species }\end{array}$} & \multicolumn{3}{|c|}{ 种类最多的科 Top families of vascular plants } & \multirow{3}{*}{$\begin{array}{l}\text { 单属单种科数 } \\
\text { Families with } \\
\text { single genus } \\
\text { and single } \\
\text { species }\end{array}$} \\
\hline & & & & \multirow[t]{2}{*}{$\begin{array}{ll}\text { 科 Family } \\
\end{array}$} & \multicolumn{2}{|c|}{$\begin{array}{c}\text { 百分比 } \\
\text { Percentage \% }\end{array}$} & \\
\hline & & & & & $\begin{array}{c}\text { 属 } \\
\text { Genus }\end{array}$ & $\begin{array}{c}\text { 种 } \\
\text { Species }\end{array}$ & \\
\hline $\begin{array}{l}\text { 白龙江 } \\
\text { Bailongjiang River }\end{array}$ & 63 & 125 & 153 & $\begin{array}{l}\text { 禾本科、菊科、蓄薇科、蝶形花科 } \\
\text { Gramineae, Compositae, Rosaceae, Fabaceae }\end{array}$ & 32.80 & 37.25 & 38 \\
\hline $\begin{array}{l}\text { 大渡河 } \\
\text { Daduhe River }\end{array}$ & 80 & 174 & 239 & $\begin{array}{l}\text { 菊科、禾本科、蝶形花科、百合科 } \\
\text { Compositae, Gramineae, Fabaceae, Liliaceae }\end{array}$ & 31.61 & 32.22 & 33 \\
\hline $\begin{array}{l}\text { 金沙江下段 } \\
\text { Jinshajiang River } \\
\text { Downstream }\end{array}$ & 145 & 597 & 1,174 & $\begin{array}{l}\text { 菊科、禾本科、蝶形花科、蓄薇科 } \\
\text { Compositae, Gramineae, Fabaceae, Rosaceae }\end{array}$ & 29.65 & 29.56 & 40 \\
\hline $\begin{array}{l}\text { 金沙江上段 } \\
\text { Jinshajiang River } \\
\text { Upstream }\end{array}$ & 118 & 401 & 714 & $\begin{array}{l}\text { 菊科、禾本科、蝶形花科、蓄薇科 } \\
\text { Compositae, Gramineae, Fabaceae, Rosaceae }\end{array}$ & 31.42 & 33.19 & 40 \\
\hline $\begin{array}{l}\text { 澜沧江 } \\
\text { Lancangjiang River }\end{array}$ & 138 & 465 & 882 & $\begin{array}{l}\text { 菊科、禾本科、蝶形花科、蓄薇科 } \\
\text { Compositae, Gramineae, Fabaceae, Rosaceae }\end{array}$ & 28.17 & 31.41 & 37 \\
\hline $\begin{array}{l}\text { 㞾江 } \\
\text { Minjiang River }\end{array}$ & 39 & 82 & 99 & $\begin{array}{l}\text { 菊科、蓄薇科、蝶形花科、禾本科 } \\
\text { Composita, Rosaceae, Fabaceae, Gramineae }\end{array}$ & 37.80 & 41.41 & 19 \\
\hline $\begin{array}{l}\text { 南盘江 } \\
\text { Nanpanjiang River }\end{array}$ & 66 & 163 & 206 & $\begin{array}{l}\text { 禾本科、菊科、蝶形花科、大戟科 } \\
\text { Gramineae, Compositae, Fabaceae, Euphorbiaceae }\end{array}$ & 37.42 & 37.86 & 36 \\
\hline $\begin{array}{l}\text { 怒江 } \\
\text { Nujiang River }\end{array}$ & 161 & 621 & 1,176 & $\begin{array}{l}\text { 禾本科、菊科、蝶形花科、唇形科 } \\
\text { Gramineae, Compositae, Fabaceae, Labiatae }\end{array}$ & 27.05 & 26.02 & 44 \\
\hline $\begin{array}{l}\text { 雅聋江 } \\
\text { Yalongjiang River }\end{array}$ & 73 & 164 & 240 & $\begin{array}{l}\text { 菊科、蝶形花科、唇形科、葍薇科 } \\
\text { Compositae, Fabaceae, Labiatae, Rosaceae }\end{array}$ & 29.27 & 31.67 & 35 \\
\hline $\begin{array}{l}\text { 元江 } \\
\text { Yuanjiang River }\end{array}$ & 89 & 338 & 496 & $\begin{array}{l}\text { 禾本科、蝶形花科、菊科、大戟科 } \\
\text { Gramineae, Fabaceae, Compositae, Euphorbiaceae }\end{array}$ & 36.09 & 40.32 & 30 \\
\hline
\end{tabular}

分布 $(4.2 \%) 、$ 东亚(东喜马拉雅-日本)分布 $(3.9 \%)$ 、 中国-喜马拉雅分布 $(3.7 \%)$ 、温带亚洲分布 $(2.3 \%) 、$ 中国-日本分布 $(2.1 \%)$ 、中国特有分布 $(1.7 \%)$ 、地中 海区、西亚至中亚分布 $(1.5 \%)$ 、中亚分布 $(0.3 \%)$ (表 4)。热带分布属(分布型2-7)有524属, 占总属数的 $55.4 \%$; 温带分布属 (分布型 8-13) 为 313 属, 占 $33.1 \%$ ，其中北方温带成分的属(分布型8-11)为296 属, 占总数的 $31.3 \%$, 古地中海成分的属 $($ 分布型 12-13)为 17 属, 占 $1.8 \%$, 东亚成分的属(分布型 14 及 其 2 个亚型, 15$)$ 为 108 属, 占 $11.4 \%$ 。

各流域干旱河谷种子植物区系的属级区系成 分均以泛热带分布和北方温带分布为主, 而温带成 分所占比例在属级远高于科级。此外, 岷江无热带 亚洲和热带美洲间断分布分布型; 南盘江、怒汇、 元江不存在代表温带荒漠成分的中亚分布型; 南盘 江无中国-喜马拉雅分布型, 㞾江、雅聋江没有中国 -日本分布型; 而雅聋江无中国特有分布属。其余12 个分布型在西南干旱河谷各江段均有分布(表4)。

\section{3 古地中海成分的分布比较}

科水平没有古地中海成分的分布，而属水平古
地中海成分的比例为 $1.8 \%$, 包括 17 个属 2 个分布型, 其中木犀榄属 $(\mathrm{Olea}) 、$ 陇牛儿苗属(Erodium)、小蓬 属(Nanophyton)等14个属为地中海区-西亚至中亚 分布, 紫苑木属(Asterothamnus)、对节刺属(Horaninovia)、角蒿属(Incarvillea) 等3个属为中亚分布。

不同流域的古地中海成分比例从大到小依次 为岷江、白龙江、大渡河、雅聋江、金沙江上段金沙江下段-澜沧江、怒江、元江、南盘江(表4)。 其中: 地中海区-西亚至中亚分布的比例从大到小依 次为白龙江、大渡河、澜沧江-怒江、金沙江上段金沙江下段-岷江-元江、雅狵江、南盘江; 中亚分布 的比例从大到小依次为岷江、白龙江、雅䶭江、大 渡河、金沙江下段、金沙江上段-澜沧江(表4)。

从区内的西南向东北方向, 古地中海成分的比 例逐渐增加, 表明与古地中海的联系逐渐增强; 地 中海区-西亚至中亚分布, 以及中亚分布也有类似 的格局。

\section{4 热带成分/温带成分的分布比较}

在整个研究区域, 植物区系中科级的热带成分 与温带成分比值为 3.06 , 不同流域从大到小依次为 


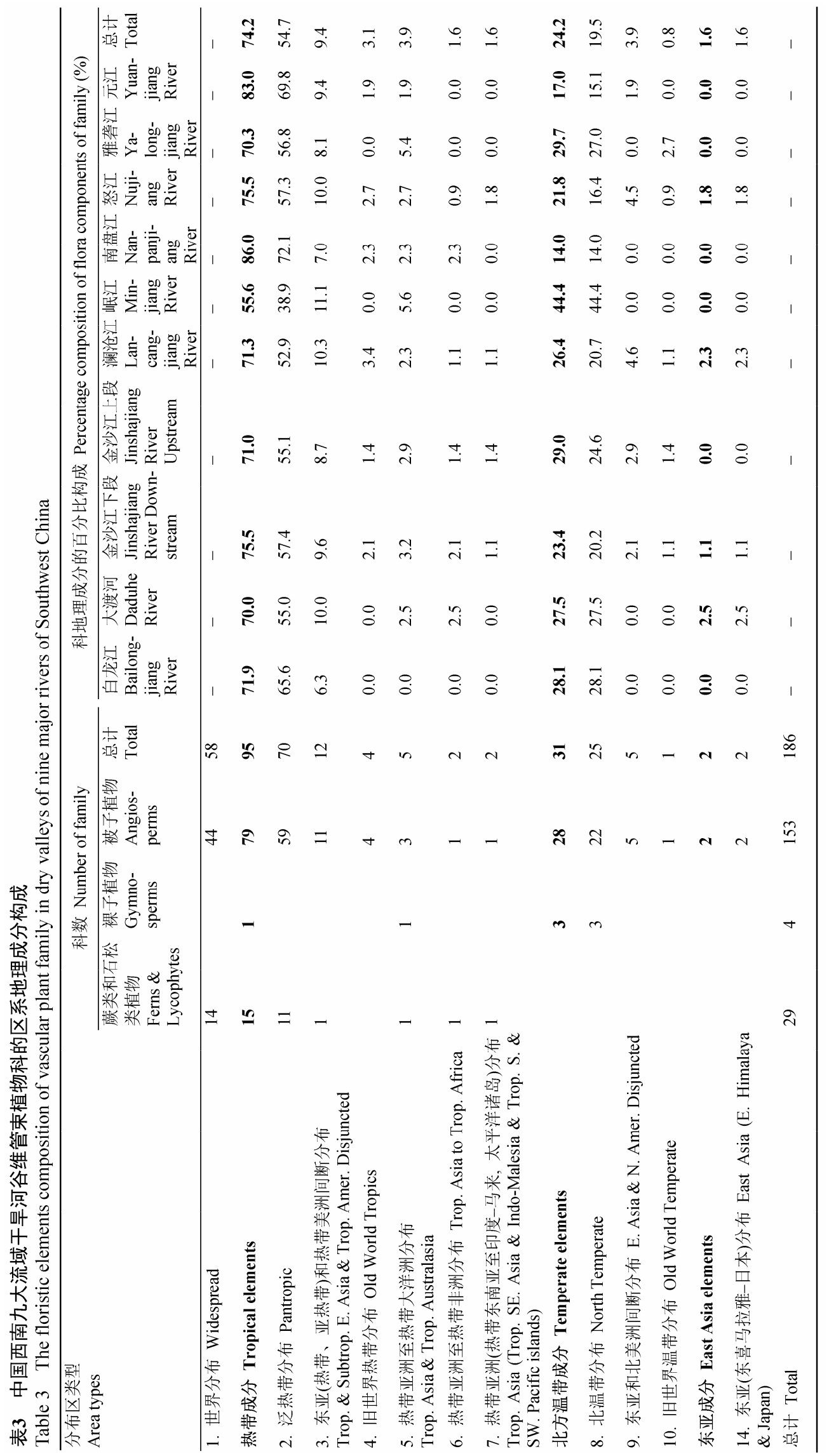




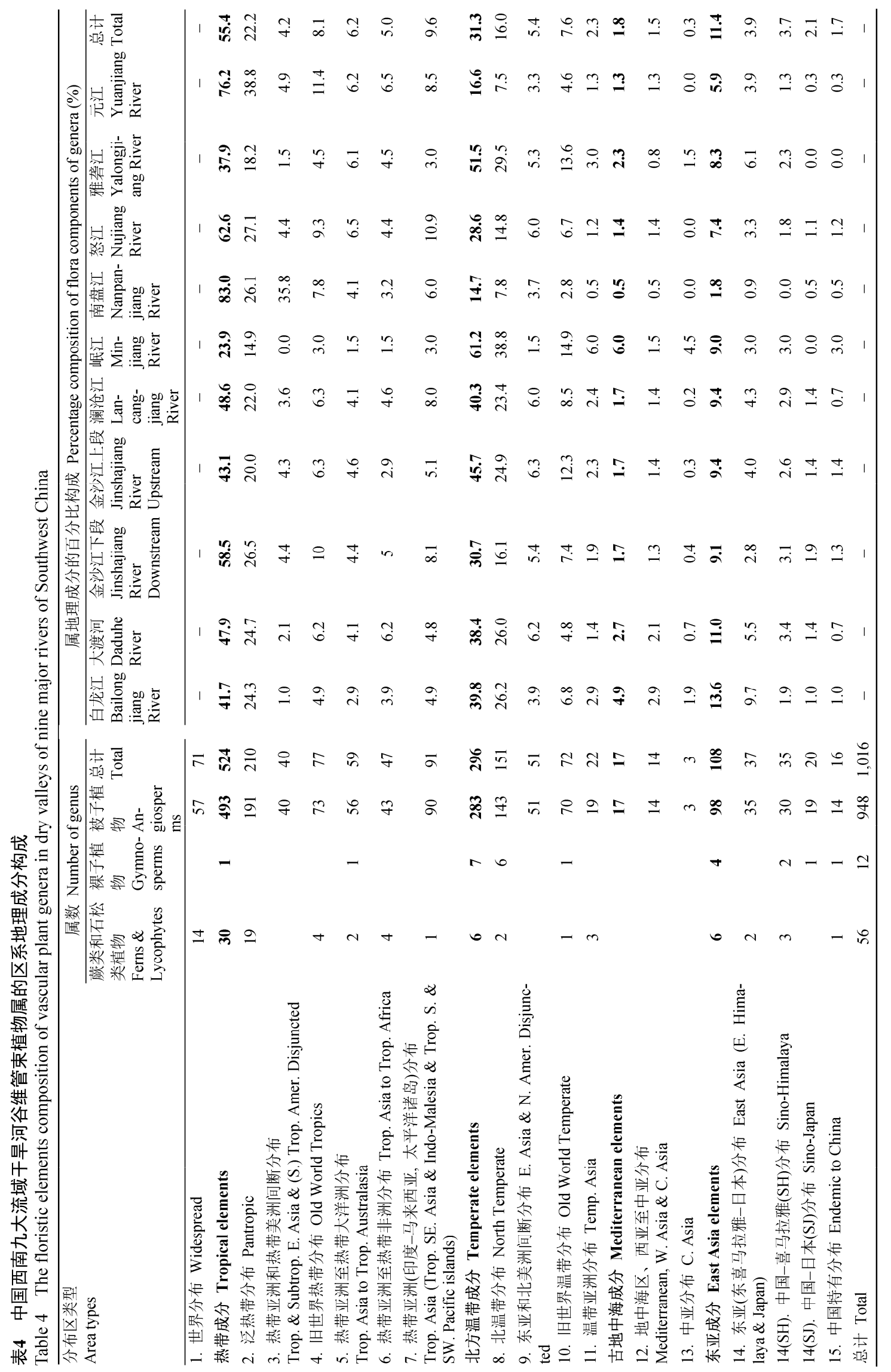


表5 西南各流域干旱河谷维管束植物科、属水平热带成分与温带成分的比值

Table 5 Tropical / temperate floristic elements ratio of vascular plants at family and genus level in dry valleys of Southwest China

\begin{tabular}{|c|c|c|c|c|c|c|c|c|c|c|}
\hline $\begin{array}{l}\text { 分类等级 } \\
\text { Taxonomic level }\end{array}$ & $\begin{array}{l}\text { 白龙江 } \\
\text { Bailongjiang } \\
\text { River }\end{array}$ & $\begin{array}{l}\text { 大渡河 } \\
\text { Daduhe } \\
\text { River }\end{array}$ & $\begin{array}{l}\text { 金沙江下段 } \\
\text { Jinshajiang } \\
\text { River } \\
\text { Downstream }\end{array}$ & $\begin{array}{l}\text { 金沙江上段 } \\
\text { Jinshajiang } \\
\text { River } \\
\text { Upstream }\end{array}$ & $\begin{array}{l}\text { 澜沧江 } \\
\text { Lancang- } \\
\text { jiang } \\
\text { River }\end{array}$ & $\begin{array}{l}\text { 岷江 } \\
\text { Min- } \\
\text { jiang } \\
\text { River }\end{array}$ & $\begin{array}{l}\text { 南盘江 } \\
\text { Nanpan- } \\
\text { jiang } \\
\text { River }\end{array}$ & $\begin{array}{l}\text { 怒江 } \\
\text { Nujiang } \\
\text { River }\end{array}$ & $\begin{array}{l}\text { 雅䶭江 } \\
\text { Yalong- } \\
\text { jiang } \\
\text { River }\end{array}$ & $\begin{array}{l}\text { 元江 } \\
\text { Yuan- } \\
\text { jiang } \\
\text { River }\end{array}$ \\
\hline 科 Family & 2.56 & 2.55 & 3.23 & 2.45 & 2.70 & 1.25 & 6.17 & 3.46 & 2.36 & 4.89 \\
\hline 属 Genus & 1.05 & 1.25 & 1.90 & 0.94 & 1.20 & 0.39 & 5.66 & 2.18 & 0.74 & 4.59 \\
\hline
\end{tabular}

南盘江、元江、怒江、金沙江下段、澜沧江、白龙 江、大渡河、金沙江上段、雅砻江、岷江(表5), 大 致反映了纬度对热带和温带区系成分分布的影响。

属级植物区系热带成分与温带成分的比值为 1.77 , 反映了温带成分的影响在区系发育近期增 强。不同流域比值从大到小依次为南盘江、元江、 怒江、金沙江下段、大渡河、澜沧江、白龙江、金 沙江上段、雅聋江、峮江(表5)。从西南向东北，以 及随着河谷平均海拔的上升, 热带成分与温带成分 的比值逐渐减小, 热带性质逐渐减弱, 温带性质逐 渐增强。

\section{5 东亚成分的分布比较}

科水平东亚成分的比例为 $1.6 \%$, 仅怒江、澜沧 江、金沙江下段和大渡河 4 个流域有东亚成分的分 布，该比例从大到小依次为澜沧江、大渡河、怒江、 金沙江下段(表3)。

属水平东亚成分的比例为 $11.4 \%$, 不同流域比 例从大到小依次为白龙江、大渡河、澜沧江、金沙 江上段-金沙江下段、峮江、怒江、雅若江、元江、 南盘江。其中中国-喜马拉雅分布的比例从大到小 依次为大渡河、金沙江下段、澜沧江、岷江、金沙 江上段、雅聋江、白龙江-怒江、元江，在南盘江流 域没有分布; 中国-日本分布的比例从大到小依次

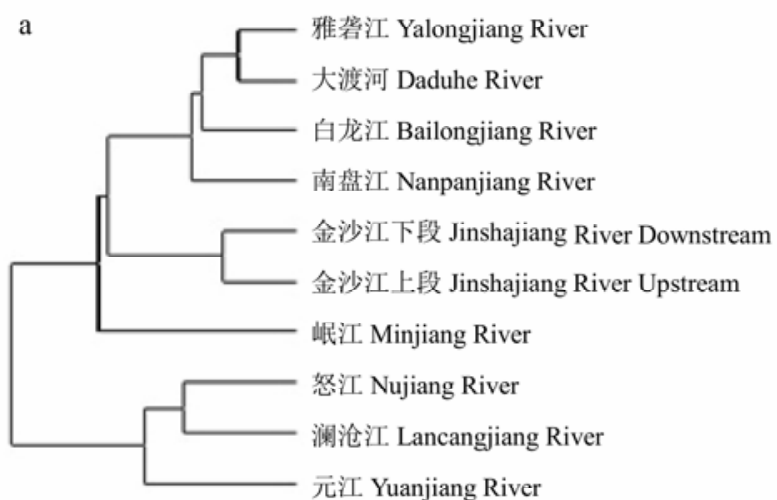

为金沙江下段、澜沧江、金沙江上段、大渡河、怒 江、白龙江、南盘江、元江，而在怅江和雅䶭江流 域没有分布; 中国特有分布的比例从大到小依次为 岷江、金沙江上段-金沙江下段、怒江、白龙江、 大渡河-澜沧江、南盘江、元江，雅聋江流域没有中 国特有属的分布(表4)。

因此，从西南向东北，东亚成分的比例逐渐增 加, 与东亚的联系逐渐增强; 除南盘江外, 其余 9 个 流域干旱河谷的植物区系与喜马拉雅地区的联系 均高于与日本的联系, 且中心区域与喜马拉雅和日 本的联系高于周边区域。

\section{6 不同流域植物区系组成相似性}

综上所述，西南各流域干旱河谷植物区系成分 呈现了西南-东北方向的空间梯度分异。其区系成 分组成相似性也表现出类似的空间格局(图2)。

科水平上(图2a)，10个流域首先分为 2 组: 位于 西南部的怒江、元江和澜沧江河谷为一组; 另一组 中, 雅䶭江、大渡河、白龙江、南盘江相似性较高, 与金沙江(含上, 下段)河谷的相似性较低, 与岷江 的相似性更低。同样, 在属水平上(图2b), 西南部的 元江、怒江、澜沧江和金沙江干旱河谷区系成分分 为一组, 其中元江更为特殊; 而甘肃、四川境内的 其他河流为另一组。

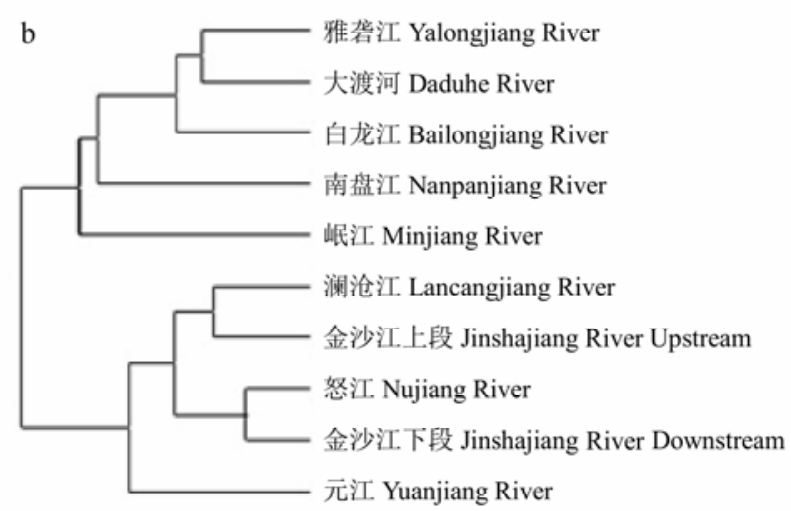

图2 中国西南不同流域干旱河谷的植物区系成分相似性。a: 科区系, b: 属区系。

Fig. 2 The similarity of flora types among dry valleys at family and genus level. a, family flora; b, genus flora. 


\section{3 讨论}

中国亚热带地区的植物区系以泛热带和北温 带分布的地理成分为主, 相对全国来说是东亚区 系的核心地段, 特有性强(沈泽吴和张新时, 2000; 陈卫娟, $2006^{(1)}$ ); 而中国西南亚热带地区的山体为 温带性质, 以温带成分为主, 其次为东亚分布和以 泛热带为主的热带成分, 热带成分随海拔上升而减 少, 温带成分随海拔上升而增加(沈泽吴等, 2004; 伍杰等, 2012)。

干旱河谷位于我国西南亚热带地区的河谷低 地, 植物区系成分主要为泛热带分布、北温带分布、 热带亚洲分布，以热带成分为主，其次是温带成分， 并有一定的东亚成分和少数的古地中海成分, 中国 特有属16属, 占中国种子植物特有分布属239属(吴 征镒等, 2011)的 $7 \%$ 。从科到属的区系地理成分构成 中, 温带成分显著增加, 体现了热带向温带过渡的 区系特征, 与我国亚热带植物区系的性质 (陈卫娟, $2006^{(1)}$; 沈泽昊和张新时, 2000)基本一致, 但由于干 旱河谷特殊的环境条件, 其东亚成分的比例很小, 特有度低于亚热带区域的平均水平, 反映了本区植 物区系的交汇过渡性质, 而特有性在各流域的差 异, 说明了各流域古老性和孤立性程度的不同(应 俊生和张志松, 1985; 苏志尧, 1999)。

东亚成分中, 除南盘江外, 其他各流域均为中 国-喜马拉雅分布多于中国-日本分布, 表明本区与 喜马拉雅植物区系有更近的亲缘, 并且这两个变型 的总和明显超过了典型东亚成分, 说明东亚成分在 元江与南盘江之间存在显著的过渡性, 该结果很好 地支持了 “田中线”假说(Tanaka，1954; 李锡文和李 捷, 1992; Li \& Li, 1997), 表明红河断裂带对云南植 物地理的影响在干旱河谷植物区系的分化中同样 明显, 与针对云南植物区系分异的早期相关结果一 致(朱华和阎丽春, 2003)。

本区与古地中海地区的联系共有 17 属, 其中与 地中海、西亚等地联系的有 14 属, 与中亚联系的仅 有3属, 反映了其与古地中海, 特别是地中海-西亚 地区植物区系的渊源, 但这一联系并不突出。与中 亚地区的区系联系很弱, 这与喜马拉雅山脉的隆 起, 以及青藏高原的旱化和寒化, 导致两者所处环

(1) 陈卫娟 (2006) 中亚热带常绿阔叶林植物区系地理研究. 华东师范 大学硕士学位论文, 上海.
境在水热方面的差异很大有关(朱釒金金, 2014)。沈泽 昊和张新时(2000)统计了我国亚热带76个区域植物 区系的属级地理成分构成; 地中海区，西亚至中亚 成分所占比例的平均值为 $0.82 \%$; 中亚成分比例的 均值为 $0.21 \%$ 。相比而言, 西南干旱河谷植物区系 中，南盘江和雅聋江的地中海、西亚至中亚成分的 百分比低于亚热带区域平均值，澜沧江、怒江、元 江和南盘江的中亚成分低于区域平均值。显示古地 中海植物区系对当前西南干旱河谷植物区系的影 响主要保留在区内偏东北部, 而非目前西南季风影 响强烈的西南部分。

以流域为单位的植物区系组成相似性主要呈 现了西南和东北的分化。从西南向东北, 热带性质 逐渐减弱, 温带性质逐渐增强, 且与古地中海和东 亚区系的联系逐渐增强, 特有性逐渐增加, 这一空 间分异格局既可联系到水热条件的梯度差异(刘晔, 2015), 也应与河流发育的历史过程有关。青藏高原 隆升以后, 长江溯源侵蚀, 导致河流袭夺自东向西 的发生(崔之久等, 1998; 杨达源等, 2008), 嘉陵江、 岷江、金沙江先后被纳入长江流域体系, 应对其上 游各支流干旱河谷的植物区系构成产生深刻影响 (张体操, 2010; Zhang et al, 2011; 朱金金金, 2014), 并 使之与迄今仍在长江流域以外的怒江、澜沧江和 元江(包括其干旱河谷段)的植物区系保持更大的 差异。

目前, 关于西南诸河流的干旱河谷缺乏全面的 植物区系调查资料。本文基于植物群落的样方调查 法, 对各干旱河谷植被进行了系统地植物采集调 查, 并综合了部分干旱河谷的植物区系调查数据, 基于一个不完整但具代表性的物种样本完成相关 分析。为了降低研究结果的不确定性, 我们针对植 物科、属水平进行区系分析。今后我们将在进一步 完善植物区系分布数据的基础上，深化相关研究。

致谢: 衷心感谢北京大学生态系沈利峰、王韬、张 婉君、秦思雨、李鹏、杨健、许玥、应凌霄等同学 在野外调查中的付出! 衰心感谢赵子恩先生、石松 林博士在标本鉴定方面给与的帮助。

\section{参考文献}

Bao WK, Wang CM (2000) Degradation mechanism of mountain ecosystem at the dry valley in the upper reaches of the Minjiang River. Journal of Mountain Science, 18, 57-62. (in Chinese with English abstract) [包维楷, 王春明 (2000) 岷 
江上游山地生态系统的退化机制. 山地学报, 18, 57-62.]

Barbour GB (1936) Physiographic history of the Yangtze. Geographical Journal, 87, 17-32.

Cao YH, Jin ZZ (1993) A research on the flora of Nujiang dry-hot valley in Lujiangba, Yunnan. Guihaia, 15, 132-138. (in Chinese with English abstract) [曹永恒, 金振洲 (1993) 云南潞江坝怒江干热河谷植被研究. 广西植物, 15 , 132-138.]

Clark MK, Schoenbohm LM, Royden LH, Whipple KX, Burchfiel BC, Zhang X, Tang W, Wang E, Chen L (2004) Surface uplift, tectonics, and erosion of eastern Tibet from large-scale drainage patterns. Tectonics, 23, 1006.

Cui ZJ, Wu YQ, Liu GN, Ge DK, Pang QQ, Xu QH (1998) About "Kunlun-Yellow River" tectonic movement. Science in China, 28, 53-59. (in Chinese) [崔之久, 伍永秋, 刘耕 年, 葛道凯, 庞其清, 许清海 (1998) 关于“昆仑一黄河运 动”. 中国科学, 28, 53-59.]

Editorial Committee of Flora Republicae Popularis Sinicae (1959-2004) Flora Republicae Popularis Sinicae. Science Press, Beijing. (in Chinese) [中国植物志编辑委员会 (1959-2004) 中国植物志. 科学出版社, 北京.]

Jin ZZ (1998) Study on the floristic elements of seed plants in the dry-warm valleys of Yunnan and Sichuan. Guihaia, 18, 313-321. (in Chinese with English abstract) [金振洲 (1998) 滇川干暖河谷种子植物区系成分研究. 广西植物, 18 , 313-321.]

Jin ZZ (1999) Study on the floristic elements of seed plants in the dry-hot valleys of Yunnan and Sichuan. Guihaia, 19, 1-14. (in Chinese with English abstract) [金振洲 (1999) 滇 川干热河谷种子植物区系成分研究. 广西植物, 19, 1-14.]

Jin ZZ (2002) Floristic Features of Dry-hot and Dry-warm Valleys, Yunnan and Sichuan. Yunnan Science \& Technology Press, Kunming. (in Chinese) [金振洲 (2002) 滇川干 热河谷与干暖河谷植物区系特征. 云南科技出版社, 昆 明.]

Jin ZZ, Ou XK (2000) Yuanjiang, Nujiang, Jinshajiang, Lancangjiang Vegetation of Dry-Hot Valley. Yunnan University Press, Yunnan Science \& Technology Press, Kunming. (in Chinese) [金振洲，欧晓昆 (2000) 元江、怒江、金沙江、 澜沧江干热河谷植被. 云南大学出版社, 云南科技出版 社, 昆明.]

Jin ZZ, Yang YP, Tao GD (1995) The floristic characteristics, nature and origin of seed plants in the dry-hot valley of Southwest China. Acta Botanica Yunnanica, 17, 129-143. (in Chinese with English abstract) [金振洲, 杨永平, 陶国 达 (1995) 华西南干热河谷种子植物区系的特征, 性质 和起源. 云南植物研究, 17, 129-143.]

Li XW, Li J (1992) On the validity of Tanaka Line and its significance viewed from the distribution of eastern Asiatic genera in Yunnan. Acta Botanica Yunnanica, 14, 1-12. (in Chinese with English abstract) [李锡文, 李捷 (1992) 从滇 产东亚属的分布论述田中线的真实性和意义. 云南植物 研究, 14, 1-12.]

Li XW, Li J (1997) The Tanaka-Kaiyong line: an important floristic line for the study of the flora of East Asia. Annals of the Missouri Botanic Garden, 84, 888-892.

Liu LH (1989) Vegetational types of the arid valleys in the Hengduan Mountains region. Mountain Research, 7, 175-182. (in Chinese with English abstract) [刘伦辉 (1989) 横断山区干旱河谷植被类型. 山地研究, 7, 175-182.]

Liu Y (2015) Plant Diversity and Phytogeography of Arid Valley in Major Rivers of the Southwestern China. PhD dissertation, Peking University, Beijing. (in Chinese with English abstract) [刘晔 (2015) 中国西南干旱河谷植被与植物多 样性空间格局与生物地理机制. 博士学位论文, 北京大 学, 北京.]

Liu Y, Li P, Xu Y, Shi SL, Ying LX, Zhang WJ, Peng PH, Shen ZH (2016) Quantitative classification and ordination for plant communities in dry valleys of Southwest China. Biodiversity Science, 24, 378-388. (in Chinese with English abstract) [刘晔, 李鹏, 许玥, 石松林, 应凌霄, 张婉君, 彭培好, 沈泽昊 (2016) 中国西南干旱河谷植物群落的 数量分类和排序分析. 生物多样性, 24, 378-388.]

Ming QZ (2006) The Landform Development and Environment Effects in the Area of Three Parallel Rivers, Northern Longitudinal Range-gorge Region. PhD dissertation, Lanzhou University, Lanzhou. (in Chinese with English abstract) [明 庆忠 (2006) 纵向岭谷北部三江并流区河谷地貌发育及 其环境效应研究. 博士学位论文, 兰州大学, 兰州.]

Ou XK, Zhang ZM, Wang CY, Wu YC (2006) Meri Snow Mountain Vegetation Research. Science Press, Beijing. (in Chinese) [欧晓昆, 张志明, 王崇云, 吴玉成 (2006) 梅里 雪山植被研究. 科学出版社, 北京.]

Peng H, Wu ZY (1997) On the floristic relationships and position of seed plants in Mt. Wuliangshan. Mountain Research, 15(3), 1-6. (in Chinese with English abstract) [彭华, 吴征 镒 (1997) 滇中南无量山种子植物区系联系及其地位. 山地研究, 15(3), 1-6.]

Qiu ZQ, Yang YH, Cao XW, Sun PJ, Sun XG (2007) Species diversity and floristic characteristics of woody plants in the dry valley of the Bailong River, China. Journal of Gansu Agricultural University, 42(5), 119-125. (in Chinese with English abstract) [邱祖青, 杨永宏, 曹秀文, 孙培坚, 孙学 刚 (2007) 白龙江干旱河谷木本植物多样性及其区系地 理特征. 甘肃农业大学学报, 42(5), 119-125.]

Ren ME, Bao HS, Han TC, Wang FY, Huang PH (1959) The landform and river capture in Jinshajiang valley in northwest Yunnan. Acta Geographica Sinica, 25, 135-155. (in Chinese with English abstract) [任美锷, 包浩生, 韩同春, 王飞燕, 黄培华 (1959) 云南西北部金沙江河谷地貌与河流袭夺 问题. 地理学报, 25, 135-155.]

Shen ZH, Liu ZL, Wu J (2004) Altitudinal pattern of flora on the eastern slope of Mt. Gongga. Biodiversity Science, 12, 89-98. (in Chinese with English abstract) [沈泽昊, 刘增力, 伍杰 (2004) 贡嘎山东坡植物区系的垂直分布格局. 生 物多样性, 12, 89-98.]

Shen ZH, Zhang XS (2000) A quantitative analysis on the floristic elements of the Chinese subtropical region and their 
spatial patterns. Acta Phytotaxonomica Sinica, 38, 366-380. (in Chinese with English abstract) [沈泽吴, 张新时 (2000) 中国亚热带地区植物区系地理成分及其空间格局的数量 分析. 植物分类学报, 38, 366-380.]

Song YC (2001) Vegetation Ecology. East China Normal University Press, Shanghai. (in Chinese) [宋永昌 (2001) 植被 生态学. 华东师范大学出版社, 上海.]

Su ZY (1999) Quantification of floristic endemism. Journal of South China Agricultural University, 20, 92-96. (in Chinese with English abstract) [苏志尧 (1999) 植物特有现象的量 化. 华南农业大学学报, 20, 92-96.]

Sun H, Li ZM (2003) Qinghai-Tibet Plateau uplift and its impact on Tethys flora. Advance in Earth Sciences, 18, 852-862. (in Chinese with English abstract) [孙航, 李志敏 (2003) 古地中海植物区系在青藏高原隆起后的演变和发 展. 地球科学进展, 18, 852-862.]

Tanaka T (1954) Species Problem in Citrus, pp. 58-69. Japanese Society for the Promotion of Science, Tokyo.

Vetaas OR, Grytnes JA (2002) Distribution of vascular plant species richness and endemic richness along the Himalayan elevation gradient in Nepal. Global Ecology and Biogeography, 11, 291-301.

Wang HS (1997) Floristic Geography of North China. Science Press, Beijing. (in Chinese) [王荷生 (1997) 华北植物区系 地理. 科学出版社, 北京.]

Wu J, Yin XM, Liu ZF, Ruan JY (2012) Research on seed plant flora in Gongga Mountain Nature Reserve. Journal of Sichuan Forestry Science and Technology, 33, 46-49. (in Chinese with English abstract) [伍杰, 尹学明, 刘兆发, 阮 建英 (2012) 贡嘎山自然保护区种子植物区系研究. 四 川林业科技, 33, 46-49.]

Wu ZY, Chen XQ (2004) Flora Republicae Popularis Sinicae, Vol.1. Science Press, Beijing. (in Chinese) [吴征镒, 陈心 启 (2004) 中国植物志第一卷. 科学出版社, 北京.]

Wu ZY, Wang HS (1983) Phytogeography of China. Science Press, Beijing. (in Chinese) [吴征镒, 王荷生 (1983) 中国 自然地理. 科学出版社, 北京.]

Wu ZY, Sun H, Zhou ZK, Li DZ, Peng H (2011) Floristics of Seed Plants from China. Science Press, Beijing. (in Chinese) [吴征镒, 孙航, 周浙昆, 李德铢, 彭华 (2011) 中国种子 植物区系地理. 科学出版社, 北京.]

Yang DY, Han ZY, Ge ZS, Xu QM, Chen KF, Xu YH, Li LP, Huang D, Lu HY (2008) Geomorphic process of the formation and incision of the section from Shigu to Yibin of the Jinshajiang River. Quaternary Sciences, 28, 564-568. (in Chinese with English abstract) [杨达源, 韩志勇, 葛兆帅, 胥勤勉, 陈可峰, 徐永辉, 李郎平, 黄典, 鹿化显 (2008) 金沙江石鼓-宜宾河段的贯通与深切地貌过程的研究. 第
四纪研究, 28, 564-568.]

Yang QY, Zheng D (1989) An outline of physic-geographic regionalization of the Hengduan mountainous region. Mountain Research, 7, 56-64. (in Chinese with English abstract) [杨勤业, 郑度 (1989) 横断山区综合自然区划纲 要. 山地研究, 7, 56-64.]

Ying JS, Chen ML (2011) Chinese Plant Geography. Shanghai Science \& Technology Press, Shanghai. (in Chinese) [应俊 生, 陈梦玲 (2011) 中国植物地理. 上海科学技术出版 社, 上海.]

Ying JS, Zhang ZS (1985) Endemism in the flora of China: studies on the endemic genera. Acta Phytotaxonomica Sinica, 22, 259-268. (in Chinese with English abstract) [应 俊生, 张志松 (1985) 中国植物区系中的特有现象: 特有 属研究. 植物分类学报, 22, 259-268.]

Zhang RZ (1992) The Dry Valleys of the Hengduan Mountains Region. Science Press, Beijing. (in Chinese) [张荣祖 (1992) 横断山区干旱河谷. 科学出版社, 北京.]

Zhang TC (2010) Phylogeography and Phylogeny of Terminalia franchetii and Its Correlation with Honghe Diversion Events. PhD dissertation, Kunming Institute of Botany, Chinese Academy of Sciences, Kunming. (in Chinese with English abstract) [张体操 (2010) 滇榄仁谱系地理学, 种 系分异及其与红河水系变迁的关系研究. 博士学位论文, 中国科学院昆明植物研究所, 昆明.]

Zhang TC, Comes HP, Sun H (2011) Chloroplast phylogeography of Terminalia franchetii (Combretaceae) from the eastern Sino-Himalayan region and its correlation with historical river capture events. Molecular Phylogenetics and Evolution, 60, 1-12.

Zhu H (1990) A study on the thorny succulent shrubs in dry-hot valley of Yuanjiang County. Acta Botanica Yunnanica, 12, 301-310. (in Chinese with English abstract) [朱华 (1990) 元江干热河谷肉质多刺灌从的研究. 云南植物研究, 12 , 301-310.]

Zhu H, Yan LC (2003) Notes on the realities and significances of the "Tanaka Line" and the "Ecogeographical Diagonal Line" in Yunnan. Advance in Earth Sciences, 18, 870-876. (in Chinese with English abstract) [朱华, 阎丽春 (2003) 再论“田中线”和 “滇西-滇东南生态地理(生物地理)对角 线”的真实性和意义. 地球科学进展, 18, 870-876.]

Zhu XX (2014) The Flora of Seed Plants in Three Rivers Valley of SW China. PhD dissertation, Kunming Institute of Botany, Chinese Academy of Sciences, Kunming. (in Chinese with English abstract) [朱金金金鍂 (2014) 华西南三江河 谷种子植物区系研究. 博士学位论文, 中国科学院昆明 植物研究所, 昆明.]

(责任编委: 朱华 责任编辑: 问文杰)

\section{附录 Supplementary Material}

附录1 西南干旱河谷维管束植物科、属区系地理成分

Appendix 1 The floristic elements composition of vascular plant family and genera in dry valleys of Southwest China http://www.biodiversity-science.net/fileup/PDF/2015240-1.pdf 
刘晔, 朱金金金, 沈泽吴, 孙航. 中国西南干旱河谷植被的区系地理成分与空间分异. 生物多样性, 2016, 24 (4): 367-377. http://www.biodiversity-science.net/CN/10.17520/biods.2015240

附录1 西南干旱河谷维管束植物科、属区系地理成分

Appendix 1 The floristic elements composition of vascular plant family and genera in dry valleys of Southwest China

\begin{tabular}{|c|c|c|c|}
\hline 科 Family & 属 Genus & $\begin{array}{l}\text { 科分布区类型 } \\
\text { Family area types }\end{array}$ & $\begin{array}{l}\text { 属分布区类型 } \\
\text { Genus area types }\end{array}$ \\
\hline 爵床科 Acanthaceae & 假杜鹃属 Barleria & 2 & 2 \\
\hline 爵床科 Acanthaceae & 鳔冠花属 Cystacanthus & 2 & 7 \\
\hline 爵床科 Acanthaceae & 狗肝菜属 Dicliptera & 2 & 2 \\
\hline 爵床科 Acanthaceae & 驳骨草属 Gendarussa & 2 & 7 \\
\hline 爵床科 Acanthaceae & 山一笼鸡属 Gutzlaffia & 2 & 7 \\
\hline 爵床科 Acanthaceae & 枪刀药属 Hypoestes & 2 & 4 \\
\hline 爵床科 Acanthaceae & 鳞花草属 Lepidagathis & 2 & 2 \\
\hline 爵床科 Acanthaceae & 地皮消属 Pararuellia & 2 & 7 \\
\hline 爵床科 Acanthaceae & 肾苍草属 Phaulopsis & 2 & 6 \\
\hline 爵床科 Acanthaceae & 火焰花属 Phlogacanthus & 2 & 7 \\
\hline 爵床科 Acanthaceae & 马蓝属 Pteracanthus & 2 & $14(\mathrm{SH})$ \\
\hline 爵床科 Acanthaceae & 爵床属 Rostellularia & 2 & 4 \\
\hline 爵床科 Acanthaceae & 肖笼鸡属 Tarphochlamys & 2 & 7 \\
\hline 爵床科 Acanthaceae & 山牵牛属 Thunbergia & 2 & 4 \\
\hline 槭树科 Aceraceae & 槭属 Acer & 8 & 8 \\
\hline 猕猴桃科 Actinidiaceae & 狝猴桃属 Actinidia & 14 & 14 \\
\hline 猕猴桃科 Actinidiaceae & 水东哥属 Saurauia & 14 & 3 \\
\hline 猕猴桃科 Actinidiaceae & 毒药树属 Sladenia & 14 & 7 \\
\hline 龙舌兰科 Agavaceae & 龙舌兰属 Agave & 3 & 3 \\
\hline 龙舌兰科 Agavaceae & 丝兰属 Yucca & 3 & 9 \\
\hline 八角枫科 Alangiaceae & 八角枫属 Alangium & 4 & 4 \\
\hline 苋科 Amaranthaceae & 牛膝属 Achyranthes & 1 & 4 \\
\hline 苋科 Amaranthaceae & 白花苋属 Aerva & 1 & 4 \\
\hline 苋科 Amaranthaceae & 莲子草属 Alternanthera & 1 & 2 \\
\hline 苋科 Amaranthaceae & 苋属 Amaranthus & 1 & 1 \\
\hline 苋科 Amaranthaceae & 青葙属 Celosia & 1 & 2 \\
\hline 苋科 Amaranthaceae & 浆果苋属 Cladostachys & 1 & 5 \\
\hline 苋科 Amaranthaceae & 杯苋属 Cyathula & 1 & 2 \\
\hline 石蒜科 Amaryllidaceae & 仙茅属 Curculigo & 2 & 2 \\
\hline 石蒜科 Amaryllidaceae & 小金梅草属 Hypoxis & 2 & 2 \\
\hline 石蒜科 Amaryllidaceae & 石赫属 Lycoris & 2 & 14 \\
\hline 漆树科 Anacardiaceae & 山檨子属 Buchanania & 2 & 5 \\
\hline 漆树科 Anacardiaceae & 黄栌属 Cotinus & 2 & 8 \\
\hline 漆树科 Anacardiaceae & 九子母属 Dobinea & 2 & $14(\mathrm{SH})$ \\
\hline 漆树科 Anacardiaceae & 厚皮树属 Lannea & 2 & 6 \\
\hline 漆树科 Anacardiaceae & 杧果属 Mangifera & 2 & 7 \\
\hline 漆树科 Anacardiaceae & 黄连木属 Pistacia & 2 & 12 \\
\hline 漆树科 Anacardiaceae & 盐肤木属 Rhus & 2 & 8 \\
\hline 漆树科 Anacardiaceae & 三叶漆属 Terminthia & 2 & 6 \\
\hline
\end{tabular}




\begin{tabular}{|c|c|c|c|}
\hline 科 Family & 属 Genus & $\begin{array}{l}\text { 科分布区类型 } \\
\text { Family area types }\end{array}$ & $\begin{array}{l}\text { 属分布区类型 } \\
\text { Genus area types }\end{array}$ \\
\hline 漆树科 Anacardiaceae & 漆属 Toxicodendron & 2 & 9 \\
\hline 番荔枝科 Annonaceae & 假鹰爪属 Desmos & 2 & 5 \\
\hline 番荔枝科 Annonaceae & 瓜馥木属 Fissistigma & 2 & 5 \\
\hline 番荔枝科 Annonaceae & 暗罗属 Polyalthia & 2 & 4 \\
\hline 番荔枝科 Annonaceae & 紫玉盘属 Uvaria & 2 & 4 \\
\hline 夹竹桃科 Apocynaceae & 假虎刺属 Carissa & 2 & 4 \\
\hline 夹竹桃科 Apocynaceae & 夹竹桃属 Nerium & 2 & 10 \\
\hline 夹竹桃科 Apocynaceae & 杜仲藤属 Parabarium & 2 & 7 \\
\hline 夹竹桃科 Apocynaceae & 帘子藤属 Pottsia & 2 & 7 \\
\hline 夹竹桃科 Apocynaceae & 萝芙木属 Rauvolfia & 2 & 2 \\
\hline 夹竹桃科 Apocynaceae & 尖子藤属 Rhynchodia & 2 & 7 \\
\hline 夹竹桃科 Apocynaceae & 络石属 Trachelospermum & 2 & 9 \\
\hline 夹竹桃科 Apocynaceae & 纽子花属 Vallaris & 2 & 7 \\
\hline 冬青科 Aquifoliaceae & 冬青属 Ilex & 3 & 2 \\
\hline 天南星科 Araceae & 菖蒲属 Acorus & 2 & 8 \\
\hline 天南星科 Araceae & 磨芋属 Amorphophallus & 2 & 4 \\
\hline 天南星科 Araceae & 天南星属 Arisaema & 2 & 8 \\
\hline 天南星科 Araceae & 半夏属 Pinellia & 2 & $14(\mathrm{SJ})$ \\
\hline 天南星科 Araceae & 犁头尖属 Typhonium & 2 & 5 \\
\hline 天南星科 Araceae & 马蹄莲属 Zantedeschia & 2 & 8 \\
\hline 五加科 Araliaceae & 五加属 Acanthopanax & 3 & 14 \\
\hline 五加科 Araliaceae & 淴木属 Aralia & 3 & 9 \\
\hline 五加科 Araliaceae & 罗伞属 Brassaiopsis & 3 & 7 \\
\hline 五加科 Araliaceae & 掌叶树属 Euaraliopsis & 3 & 7 \\
\hline 五加科 Araliaceae & 常春藤属 Hedera & 3 & 12 \\
\hline 五加科 Araliaceae & 大参属 Macropanax & 3 & 7 \\
\hline 五加科 Araliaceae & 梁王茶属 Nothopanax & 3 & 5 \\
\hline 五加科 Araliaceae & 五叶参属 Pentapanax & 3 & 2 \\
\hline 五加科 Araliaceae & 鹅掌柴属 Schefflera & 3 & 2 \\
\hline 马兒铃科 Aristolochiaceae & 马兒铃属 Aristolochia & 2 & 2 \\
\hline 马兒铃科 Aristolochiaceae & 细辛属 Asarum & 2 & 8 \\
\hline 萝藦科 Asclepiadaceae & 马利筋属 Asclepias & 2 & 2 \\
\hline 萝藦科 Asclepiadaceae & 秦岭藤属 Biondia & 2 & 15 \\
\hline 萝藦科 Asclepiadaceae & 牛角瓜属 Calotropis & 2 & 6 \\
\hline 萝藦科 Asclepiadaceae & 吊灯花属 Ceropegia & 2 & 4 \\
\hline 萝藦科 Asclepiadaceae & 白叶藤属 Cryptolepis & 2 & 4 \\
\hline 萝藦科 Asclepiadaceae & 㧶线藤属 Cynanchum & 2 & 10 \\
\hline 萝藦科 Asclepiadaceae & 南山藤属 Dregea & 2 & 6 \\
\hline 萝藦科 Asclepiadaceae & 匙美藤属 Gymnema & 2 & 4 \\
\hline 萝藦科 Asclepiadaceae & 牛奶菜属 Marsdenia & 2 & 2 \\
\hline 萝藦科 Asclepiadaceae & 萝藦属 Metaplexis & 2 & $14(\mathrm{SJ})$ \\
\hline
\end{tabular}




\begin{tabular}{|c|c|c|c|}
\hline 科 Family & 属 Genus & $\begin{array}{l}\text { 科分布区类型 } \\
\text { Family area types }\end{array}$ & $\begin{array}{l}\text { 属分布区类型 } \\
\text { Genus area types }\end{array}$ \\
\hline 萝藦科 Asclepiadaceae & 翅果藤属 Myriopteron & 2 & 7 \\
\hline 萝藦科 Asclepiadaceae & 杜柳属 Periploca & 2 & 6 \\
\hline 萝藦科 Asclepiadaceae & 弓果藤属 Toxocarpus & 2 & 4 \\
\hline 萝藦科 Asclepiadaceae & 娃儿藤属 Tylophora & 2 & 4 \\
\hline 凤仙花科 Balsaminaceae & 凤仙花属 Impatiens & 2 & 2 \\
\hline 落葵科 Basellaceae & 落葵薯属 Anredera & 2 & 3 \\
\hline 落葵科 Basellaceae & 落葵属 Basella & 2 & 2 \\
\hline 秋海棠科 Begoniaceae & 秋海棠属 Begonia & 2 & 2 \\
\hline 小檗科 Berberidaceae & 小檗属 Berberis & 8 & 8 \\
\hline 小檗科 Berberidaceae & 十大功劳属 Mahonia & 8 & 9 \\
\hline 小檗科 Berberidaceae & 南天竹属 Nandina & 8 & $14(\mathrm{SJ})$ \\
\hline 桦木科 Betulaceae & 桤木属 Alnus & 8 & 8 \\
\hline 桦木科 Betulaceae & 桦木属 Betula & 8 & 8 \\
\hline 桦木科 Betulaceae & 鹅耳枥属 Carpinus & 8 & 8 \\
\hline 桦木科 Betulaceae & 榛属 Corylus & 8 & 8 \\
\hline 桦木科 Betulaceae & 虎榛子属 Ostryopsis & 8 & 15 \\
\hline 紫蒇科 Bignoniaceae & 凌霄属 Campsis & 2 & 9 \\
\hline 紫葳科 Bignoniaceae & 梓属 Catalpa & 2 & 9 \\
\hline 紫蒇科 Bignoniaceae & 角蒿属 Incarvillea & 2 & 13 \\
\hline 紫葳科 Bignoniaceae & 老鸦烟筒花属 Millingtonia & 2 & 7 \\
\hline 紫蒇科 Bignoniaceae & 菜豆树属 Radermachera & 2 & 7 \\
\hline 木棉科 Bombacaceae & 木棉属 Bombax & 2 & 6 \\
\hline 紫草科 Boraginaceae & 斑种草属 Bothriospermum & 1 & 14 \\
\hline 紫草科 Boraginaceae & 破布木属 Cordia & 1 & 2 \\
\hline 紫草科 Boraginaceae & 琉璃草属 Cynoglossum & 1 & 8 \\
\hline 紫草科 Boraginaceae & 厚壳树属 Ehretia & 1 & 2 \\
\hline 紫草科 Boraginaceae & 紫草属 Lithospermum & 1 & 8 \\
\hline 紫草科 Boraginaceae & 微孔草属 Microula & 1 & $14(\mathrm{SH})$ \\
\hline 紫草科 Boraginaceae & 滇紫草属 Onosma & 1 & 10 \\
\hline 紫草科 Boraginaceae & 紫筒草属 Stenosolenium & 1 & 11 \\
\hline 紫草科 Boraginaceae & 附地菜属 Trigonotis & 1 & 10 \\
\hline 醉鱼草科 Buddlejaceae & 醉鱼草属 Buddleja & 2 & 2 \\
\hline 橄榄科 Burseraceae & 嘉榄属 Garuga & 2 & 5 \\
\hline 橄榄科 Burseraceae & 马蹄果属 Protium & 2 & 2 \\
\hline 黄杨科 Buxaceae & 板発果属 Pachysandra & 8 & 9 \\
\hline 黄杨科 Buxaceae & 野扇花属 Sarcococca & 8 & 7 \\
\hline 仙人掌科 Cactaceae & 仙人柱属 Cereus & 3 & 3 \\
\hline 仙人掌科 Cactaceae & 仙人掌属 Opuntia & 3 & 3 \\
\hline 云实科 Caesalpiniaceae & 羊蹄甲属 Bauhinia & 2 & 2 \\
\hline 云实科 Caesalpiniaceae & 云实属 Caesalpinia & 2 & 2 \\
\hline 云实科 Caesalpiniaceae & 决明属 Cassia & 2 & 2 \\
\hline
\end{tabular}




\begin{tabular}{|c|c|c|c|}
\hline 科 Family & 属 Genus & $\begin{array}{l}\text { 科分布区类型 } \\
\text { Family area types }\end{array}$ & $\begin{array}{l}\text { 属分布区类型 } \\
\text { Genus area types }\end{array}$ \\
\hline 云实科 Caesalpiniaceae & 紫荆属 Cercis & 2 & 8 \\
\hline 云实科 Caesalpiniaceae & 凤凰木属 Delonix & 2 & 6 \\
\hline 云实科 Caesalpiniaceae & 㿝荚属 Gleditsia & 2 & 9 \\
\hline 云实科 Caesalpiniaceae & 老虎刺属 Pterolobium & 2 & 6 \\
\hline 云实科 Caesalpiniaceae & 酸豆属 Tamarindus & 2 & 6 \\
\hline 桔梗科 Campanulaceae & 沙参属 Adenophora & 1 & 10 \\
\hline 桔梗科 Campanulaceae & 牧根草属 Asyneuma & 1 & 10 \\
\hline 桔梗科 Campanulaceae & 风铃草属 Campanula & 1 & 8 \\
\hline 桔梗科 Campanulaceae & 金钱豹属 Campanumoea & 1 & 7 \\
\hline 桔梗科 Campanulaceae & 党参属 Codonopsis & 1 & 14 \\
\hline 桔梗科 Campanulaceae & 半边莲属 Lobelia & 1 & 2 \\
\hline 桔梗科 Campanulaceae & 桔梗属 Platycodon & 1 & $14(\mathrm{SJ})$ \\
\hline 桔梗科 Campanulaceae & 蓝花参属 Wahlenbergia & 1 & 2 \\
\hline 大麻科 Cannabaceae & 大麻属 Cannabis & 8 & 11 \\
\hline 美人蕉科 Cannaceae & 美人蕉属 Canna & 2 & 3 \\
\hline 山柑科 Capparaceae & 山柑属 Capparis & 2 & 2 \\
\hline 山柑科 Capparaceae & 白花菜属 Cleome & 2 & 2 \\
\hline 忍冬科 Caprifoliaceae & 六道木属 Abelia & 8 & 9 \\
\hline 忍冬科 Caprifoliaceae & 双盾木属 Dipelta & 8 & 15 \\
\hline 忍冬科 Caprifoliaceae & 鬼吹箫属 Leycesteria & 8 & $14(\mathrm{SH})$ \\
\hline 忍冬科 Caprifoliaceae & 忍冬属 Lonicera & 8 & 8 \\
\hline 忍冬科 Caprifoliaceae & 接骨木属 Sambucus & 8 & 8 \\
\hline 忍冬科 Caprifoliaceae & 毛核木属 Symphoricarpos & 8 & 9 \\
\hline 忍冬科 Caprifoliaceae & 莛子蔍属 Triosteum & 8 & 9 \\
\hline 忍冬科 Caprifoliaceae & 荚蒾属 Viburnum & 8 & 8 \\
\hline 石竹科 Caryophyllaceae & 无心菜属 Arenaria & 1 & 8 \\
\hline 石竹科 Caryophyllaceae & 狗筋䕊属 Cucubalus & 1 & 10 \\
\hline 石竹科 Caryophyllaceae & 石竹属 Dianthus & 1 & 10 \\
\hline 石竹科 Caryophyllaceae & 剪秋罗属 Lychnis & 1 & 8 \\
\hline 石竹科 Caryophyllaceae & 找肠菜属 Myosoton & 1 & 10 \\
\hline 石竹科 Caryophyllaceae & 金铁锁属 Psammosilene & 1 & 15 \\
\hline 石竹科 Caryophyllaceae & 蝇子草属 Silene & 1 & 8 \\
\hline 石竹科 Caryophyllaceae & 繁缕属 Stellaria & 1 & 1 \\
\hline 卫矛科 Celastraceae & 南蛇藤属 Celastrus & 2 & 2 \\
\hline 卫矛科 Celastraceae & 卫矛属 Euonymus & 2 & 1 \\
\hline 卫矛科 Celastraceae & 美登木属 Maytenus & 2 & 2 \\
\hline 藜科 Chenopodiaceae & 驼线檧属 Ceratoides & 1 & 11 \\
\hline 藜科 Chenopodiaceae & 藜属 Chenopodium & 1 & 1 \\
\hline 藜科 Chenopodiaceae & 对节刺属 Horaninowia & 1 & 13 \\
\hline 藜科 Chenopodiaceae & 地肤属 Kochia & 1 & 8 \\
\hline 藜科 Chenopodiaceae & 小蓬属 Nanophyton & 1 & 12 \\
\hline
\end{tabular}




\begin{tabular}{|c|c|c|c|}
\hline 科 Family & 属 Genus & $\begin{array}{l}\text { 科分布区类型 } \\
\text { Family area types }\end{array}$ & $\begin{array}{l}\text { 属分布区类型 } \\
\text { Genus area types }\end{array}$ \\
\hline 藜科 Chenopodiaceae & 猪毛菜属 Salsola & 1 & 1 \\
\hline 金粟兰科 Chloranthaceae & 金粟兰属 Chloranthus & 2 & 7 \\
\hline 金粟兰科 Chloranthaceae & 草珊瑚属 Sarcandra & 2 & 7 \\
\hline 使君子科 Combretaceae & 诃子属 Terminalia & 2 & 2 \\
\hline 鸭跖草科 Commelinaceae & 鸭跖草属 Commelina & 2 & 2 \\
\hline 鸭跖草科 Commelinaceae & 蓝耳草属 Cyanotis & 2 & 4 \\
\hline 鸭跖草科 Commelinaceae & 水竹叶属 Murdannia & 2 & 4 \\
\hline 鸭跖草科 Commelinaceae & 杜若属 Pollia & 2 & 2 \\
\hline 鸭跖草科 Commelinaceae & 竹叶子属 Streptolirion & 2 & $14(\mathrm{SH})$ \\
\hline 菊科 Compositae & 刺苍果属 Acanthospermum & 1 & 2 \\
\hline 菊科 Compositae & 下田菊属 Adenostemma & 1 & 2 \\
\hline 菊科 Compositae & 蕉香蓟属 Ageratum & 1 & 2 \\
\hline 菊科 Compositae & 兔儿风属 Ainsliaea & 1 & 14 \\
\hline 菊科 Compositae & 亚菊属 Ajania & 1 & 11 \\
\hline 菊科 Compositae & 香青属 Anaphalis & 1 & 8 \\
\hline 菊科 Compositae & 山黄菊属 Anisopappus & 1 & 6 \\
\hline 菊科 Compositae & 牛蒡属 Arctium & 1 & 10 \\
\hline 菊科 Compositae & 蒿属 Artemisia & 1 & 1 \\
\hline 菊科 Compositae & 紫苑属 Aster & 1 & 8 \\
\hline 菊科 Compositae & 紫苑木属 Asterothamnus & 1 & 13 \\
\hline 菊科 Compositae & 鬼针草属 Bidens & 1 & 1 \\
\hline 菊科 Compositae & 百能葳属 Blainvillea & 1 & 2 \\
\hline 菊科 Compositae & 艾纳香属 Blumea & 1 & 4 \\
\hline 菊科 Compositae & 飞廉属 Carduus & 1 & 10 \\
\hline 菊科 Compositae & 天名精属 Carpesium & 1 & 10 \\
\hline 菊科 Compositae & 毛鳞菊属 Chaetoseris & 1 & $14(\mathrm{SH})$ \\
\hline 菊科 Compositae & 茼蒿属 Chrysanthemum & 1 & 10 \\
\hline 菊科 Compositae & 蓟属 Cirsium & 1 & 8 \\
\hline 菊科 Compositae & 藤菊属 Cissampelopsis & 1 & 7 \\
\hline 菊科 Compositae & 白酒草属 Conyza & 1 & 2 \\
\hline 菊科 Compositae & 金鸡菊属 Coreopsis & 1 & 2 \\
\hline 菊科 Compositae & 秋英属 Cosmos & 1 & 3 \\
\hline 菊科 Compositae & 野茼蒿属 Crassocephalum & 1 & 6 \\
\hline 菊科 Compositae & 还阳参属 Crepis & 1 & 8 \\
\hline 菊科 Compositae & 杯菊属 Cyathocline & 1 & 7 \\
\hline 菊科 Compositae & 菊属 Dendranthema & 1 & 10 \\
\hline 菊科 Compositae & 鱼眼草属 Dichrocephala & 1 & 4 \\
\hline 菊科 Compositae & 川木香属 Dolomiaea & 1 & $14(\mathrm{SH})$ \\
\hline 菊科 Compositae & 蓝刺头属 Echinops & 1 & 10 \\
\hline 菊科 Compositae & 鳢肠属 Eclipta & 1 & 2 \\
\hline 菊科 Compositae & 地胆草属 Elephantopus & 1 & 2 \\
\hline
\end{tabular}




\begin{tabular}{|c|c|c|c|}
\hline 科 Family & 属 Genus & $\begin{array}{l}\text { 科分布区类型 } \\
\text { Family area types }\end{array}$ & $\begin{array}{l}\text { 属分布区类型 } \\
\text { Genus area types }\end{array}$ \\
\hline 菊科 Compositae & 一点红属 Emilia & 1 & 4 \\
\hline 菊科 Compositae & 菊芹属 Erechthites & 1 & 2 \\
\hline 菊科 Compositae & 飞蓬属 Erigeron & 1 & 1 \\
\hline 菊科 Compositae & 泽兰属 Eupatorium & 1 & 8 \\
\hline 菊科 Compositae & 牛膝菊属 Galinsoga & 1 & 1 \\
\hline 菊科 Compositae & 大丁草属 Gerbera & 1 & 6 \\
\hline 菊科 Compositae & 鼠䴹草属 Gnaphalium & 1 & 1 \\
\hline 菊科 Compositae & 菊三七属 Gynura & 1 & 4 \\
\hline 菊科 Compositae & 向日葵属 Helianthus & 1 & 9 \\
\hline 菊科 Compositae & 泥胡菜属 Hemistepta & 1 & 14 \\
\hline 菊科 Compositae & 狗娃花属 Heteropappus & 1 & 11 \\
\hline 菊科 Compositae & 山柳菊属 Hieracium & 1 & 8 \\
\hline 菊科 Compositae & 旋覆花属 Inula & 1 & 10 \\
\hline 菊科 Compositae & 小苦荬属 Ixeridium & 1 & 7 \\
\hline 菊科 Compositae & 苦实菜属 Ixeris & 1 & 7 \\
\hline 菊科 Compositae & 马兰属 Kalimeris & 1 & 11 \\
\hline 菊科 Compositae & 莴芭属 Lactuca & 1 & 10 \\
\hline 菊科 Compositae & 六棱菊属 Laggera & 1 & 6 \\
\hline 菊科 Compositae & 火线草属 Leontopodium & 1 & 8 \\
\hline 菊科 Compositae & 㯻吾属 Ligularia & 1 & 10 \\
\hline 菊科 Compositae & 小舌菊属 Microglossa & 1 & 6 \\
\hline 菊科 Compositae & 粘冠草属 Myriactis & 1 & 14 \\
\hline 菊科 Compositae & 紫菊属 Notoseris & 1 & 15 \\
\hline 菊科 Compositae & 栌菊木属 Nouelia & 1 & 15 \\
\hline 菊科 Compositae & 黄瓜菜属 Paraixeris & 1 & $14(\mathrm{SJ})$ \\
\hline 菊科 Compositae & 假福王草属 Paraprenanthes & 1 & 14 \\
\hline 菊科 Compositae & 蟹甲草属 Parasenecio & 1 & 10 \\
\hline 菊科 Compositae & 银胶菊属 Parthenium & 1 & 3 \\
\hline 菊科 Compositae & 苇谷草属 Pentanema & 1 & 10 \\
\hline 菊科 Compositae & 帚菊属 Pertya & 1 & 14 \\
\hline 菊科 Compositae & 毛连菜属 Picris & 1 & 10 \\
\hline 菊科 Compositae & 翅果菊属 Pterocypsela & 1 & 14 \\
\hline 菊科 Compositae & 蚤草属 Pulicaria & 1 & 10 \\
\hline 菊科 Compositae & 匹菊属 Pyrethrum & 1 & 10 \\
\hline 菊科 Compositae & 秋分草属 Rhynchospermum & 1 & 14 \\
\hline 菊科 Compositae & 蛇目菊属 Sanvitalia & 1 & 3 \\
\hline 菊科 Compositae & 风毛菊属 Saussurea & 1 & 10 \\
\hline 菊科 Compositae & 千里光属 Senecio & 1 & 1 \\
\hline 菊科 Compositae & 绢蒿属 Seriphidium & 1 & 8 \\
\hline 菊科 Compositae & 豨莶属 Siegesbeckia & 1 & 2 \\
\hline 菊科 Compositae & 蒲儿根属 Sinosenecio & 1 & $14(\mathrm{SJ})$ \\
\hline
\end{tabular}




\begin{tabular}{|c|c|c|c|}
\hline 科 Family & 属 Genus & $\begin{array}{l}\text { 科分布区类型 } \\
\text { Family area types }\end{array}$ & $\begin{array}{l}\text { 属分布区类型 } \\
\text { Genus area types }\end{array}$ \\
\hline 菊科 Compositae & 一枝黄花属 Solidago & 1 & 8 \\
\hline 菊科 Compositae & 苦芭菜属 Sonchus & 1 & 10 \\
\hline 菊科 Compositae & 戴星草属 Sphaeranthus & 1 & 4 \\
\hline 菊科 Compositae & 金钮扣属 Spilanthes & 1 & 2 \\
\hline 菊科 Compositae & 万寿菊属 Tagetes & 1 & 2 \\
\hline 菊科 Compositae & 蒲公英属 Taraxacum & 1 & 8 \\
\hline 菊科 Compositae & 肿柄菊属 Tithonia & 1 & 3 \\
\hline 菊科 Compositae & 婆罗门参属 Tragopogon & 1 & 10 \\
\hline 菊科 Compositae & 羽芒菊属 Tridax & 1 & 3 \\
\hline 菊科 Compositae & 碱苑属 Tripolium & 1 & 8 \\
\hline 菊科 Compositae & 款冬属 Tussilago & 1 & 10 \\
\hline 菊科 Compositae & 斑鸭菊属 Vernonia & 1 & 2 \\
\hline 菊科 Compositae & 苍耳属 Xanthium & 1 & 1 \\
\hline 菊科 Compositae & 黄鹤菜属 Youngia & 1 & 11 \\
\hline 菊科 Compositae & 百日菊属 Zinnia & 1 & 3 \\
\hline 牛检藤科 Connaraceae & 单叶豆属 Ellipanthus & 2 & 6 \\
\hline 旋花科 Convolvulaceae & 心萝薯属 Aniseia & 1 & 2 \\
\hline 旋花科 Convolvulaceae & 银背藤属 Argyreia & 1 & 5 \\
\hline 旋花科 Convolvulaceae & 打碗花属 Calystegia & 1 & 8 \\
\hline 旋花科 Convolvulaceae & 旋花属 Convolvulus & 1 & 1 \\
\hline 旋花科 Convolvulaceae & 菟丝子属 Cuscuta & 1 & 2 \\
\hline 旋花科 Convolvulaceae & 马蹄金属 Dichondra & 1 & 2 \\
\hline 旋花科 Convolvulaceae & 土丁桂属 Evolvulus & 1 & 2 \\
\hline 旋花科 Convolvulaceae & 番薯属 Ipomoea & 1 & 2 \\
\hline 旋花科 Convolvulaceae & 鱼黄草属 Merremia & 1 & 2 \\
\hline 旋花科 Convolvulaceae & 牵牛属 Pharbitis & 1 & 2 \\
\hline 旋花科 Convolvulaceae & 飞蛾藤属 Porana & 1 & 4 \\
\hline 马桑科 Coriariaceae & 马桑属 Coriaria & 8 & 8 \\
\hline 山荣英科 Cornaceae & 桃叶珊瑚属 Aucuba & 8 & 14 \\
\hline 山荣英科 Cornaceae & 四照花属 Dendrobenthamia & 8 & 14 \\
\hline 山荣英科 Cornaceae & 青荚叶属 Helwingia & 8 & 14 \\
\hline 山荣英科 Cornaceae & 梾木属 Swida & 8 & 8 \\
\hline 山荣英科 Cornaceae & 鞘柄木属 Toricellia & 8 & $14(\mathrm{SH})$ \\
\hline 景天科 Crassulaceae & 落地生根属 Bryophyllum & 1 & 2 \\
\hline 景天科 Crassulaceae & 瓦松属 Orostachys & 1 & 10 \\
\hline 景天科 Crassulaceae & 红景天属 Rhodiola & 1 & 8 \\
\hline 景天科 Crassulaceae & 瓦莲属 Rosularia & 1 & 12 \\
\hline 景天科 Crassulaceae & 景天属 Sedum & 1 & 8 \\
\hline 景天科 Crassulaceae & 石莲属 Sinocrassula & 1 & $14(\mathrm{SH})$ \\
\hline 十字花科 Cruciferae & 鼠耳芥属 Arabidopsis & 1 & 8 \\
\hline 十字花科 Cruciferae & 南芥属 Arabis & 1 & 8 \\
\hline
\end{tabular}




\begin{tabular}{|c|c|c|c|}
\hline 科 Family & 属 Genus & $\begin{array}{l}\text { 科分布区类型 } \\
\text { Family area types }\end{array}$ & $\begin{array}{l}\text { 属分布区类型 } \\
\text { Genus area types }\end{array}$ \\
\hline 十字花科 Cruciferae & 山芥属 Barbarea & 1 & 8 \\
\hline 十字花科 Cruciferae & 芸荎属 Brassica & 1 & 10 \\
\hline 十字花科 Cruciferae & 荠属 Capsella & 1 & 1 \\
\hline 十字花科 Cruciferae & 碎米荠属 Cardamine & 1 & 1 \\
\hline 十字花科 Cruciferae & 岩荠属 Cochlearia & 1 & 8 \\
\hline 十字花科 Cruciferae & 独行菜属 Lepidium & 1 & 1 \\
\hline 十字花科 Cruciferae & 蔊菜属 Rorippa & 1 & 1 \\
\hline 十字花科 Cruciferae & 菥营属 Thlaspi & 1 & 8 \\
\hline 葫芦科 Cucurbitaceae & 南瓜属 Cucurbita & 2 & 3 \\
\hline 葫芦科 Cucurbitaceae & 绞股蓝属 Gynostemma & 2 & 7 \\
\hline 葫芦科 Cucurbitaceae & 丝瓜属 Luffa & 2 & 2 \\
\hline 葫芦科 Cucurbitaceae & 帽儿瓜属 Mukia & 2 & 4 \\
\hline 葫芦科 Cucurbitaceae & 茅瓜属 Solena & 2 & 5 \\
\hline 葫芦科 Cucurbitaceae & 赤爮属 Thladiantha & 2 & 7 \\
\hline 葫芦科 Cucurbitaceae & 栝楼属 Trichosanthes & 2 & 5 \\
\hline 葫芦科 Cucurbitaceae & 马交儿属 Zehneria & 2 & 4 \\
\hline 莎草科 Cyperaceae & 扁穗草属 Blysmus & 1 & 8 \\
\hline 莎草科 Cyperaceae & 薪草属 Carex & 1 & 1 \\
\hline 莎草科 Cyperaceae & 莎草属 Cyperus & 1 & 1 \\
\hline 莎草科 Cyperaceae & 羊胡子草属 Eriophorum & 1 & 8 \\
\hline 莎草科 Cyperaceae & 飘拂草属 Fimbristylis & 1 & 2 \\
\hline 莎草科 Cyperaceae & 水莎草属 Juncellus & 1 & 1 \\
\hline 莎草科 Cyperaceae & 水蜈蚣属 Kyllinga & 1 & 2 \\
\hline 莎草科 Cyperaceae & 砖子苗属 Mariscus & 1 & 2 \\
\hline 莎草科 Cyperaceae & 扁莎属 Pycreus & 1 & 2 \\
\hline 莎草科 Cyperaceae & 珍珠茅属 Scleria & 1 & 2 \\
\hline 五桠果科 Dilleniaceae & 五桠果属 Dillenia & 2 & 5 \\
\hline 薯蓣科 Dioscoreaceae & 薯蓣属 Dioscorea & 2 & 2 \\
\hline 川续断科 Dipsacaceae & 川续断属 Dipsacus & 10 & 10 \\
\hline 川续断科 Dipsacaceae & 翼首花属 Pterocephalus & 10 & 10 \\
\hline 川续断科 Dipsacaceae & 双参属 Triplostegia & 10 & $14(\mathrm{SH})$ \\
\hline 茅亳菜科 Droseraceae & 茅膏菜属 Drosera & 8 & 1 \\
\hline 柿科 Ebenaceae & 柿属 Diospyros & 2 & 2 \\
\hline 胡颓子科 Elaeagnaceae & 胡颓子属 Elaeagnus & 8 & 8 \\
\hline 胡颓子科 Elaeagnaceae & 沙棘属 Hippophae & 8 & 10 \\
\hline 杜英科 Elaeocarpaceae & 杜英属 Elaeocarpus & 3 & 5 \\
\hline 杜鹃花科 Ericaceae & 树萝卜属 Agapetes & 6 & 7 \\
\hline 杜鹃花科 Ericaceae & 岩须属 Cassiope & 6 & 8 \\
\hline 杜鹃花科 Ericaceae & 白珠树属 Gaultheria & 6 & 3 \\
\hline 杜鹃花科 Ericaceae & 珍珠花属 Lyonia & 6 & 9 \\
\hline 杜鹃花科 Ericaceae & 马醉木属 Pieris & 6 & 9 \\
\hline
\end{tabular}




\begin{tabular}{|c|c|c|c|}
\hline 科 Family & 属 Genus & $\begin{array}{l}\text { 科分布区类型 } \\
\text { Family area types }\end{array}$ & $\begin{array}{l}\text { 属分布区类型 } \\
\text { Genus area types }\end{array}$ \\
\hline 杜鹃花科 Ericaceae & 杜鹃属 Rhododendron & 6 & 8 \\
\hline 杜鹃花科 Ericaceae & 越桔属 Vaccinium & 6 & 8 \\
\hline 大戟科 Euphorbiaceae & 铁苋菜属 Acalypha & 2 & 2 \\
\hline 大戟科 Euphorbiaceae & 山麻杆属 Alchornea & 2 & 2 \\
\hline 大戟科 Euphorbiaceae & 五月茶属 Antidesma & 2 & 4 \\
\hline 大戟科 Euphorbiaceae & 黑面神属 Breynia & 2 & 5 \\
\hline 大戟科 Euphorbiaceae & 土蜜树属 Bridelia & 2 & 6 \\
\hline 大戟科 Euphorbiaceae & 粗毛藤属 Cnesmone & 2 & 7 \\
\hline 大戟科 Euphorbiaceae & 巴豆属 Croton & 2 & 2 \\
\hline 大戟科 Euphorbiaceae & 核果木属 Drypetes & 2 & 2 \\
\hline 大戟科 Euphorbiaceae & 黄桐属 Endospermum & 2 & 5 \\
\hline 大戟科 Euphorbiaceae & 大戟属 Euphorbia & 2 & 1 \\
\hline 大戟科 Euphorbiaceae & 海漆属 Excoecaria & 2 & 6 \\
\hline 大戟科 Euphorbiaceae & 白饭树属 Flueggea & 2 & 4 \\
\hline 大戟科 Euphorbiaceae & 算盘子属 Glochidion & 2 & 2 \\
\hline 大戟科 Euphorbiaceae & 麻疯树属 Jatropha & 2 & 2 \\
\hline 大戟科 Euphorbiaceae & 雀舌木属 Leptopus & 2 & 5 \\
\hline 大戎科 Euphorbiaceae & 野桐属 Mallotus & 2 & 4 \\
\hline 大戟科 Euphorbiaceae & 木薯属 Manihot & 2 & 3 \\
\hline 大戟科 Euphorbiaceae & 山靛属 Mercurialis & 2 & 10 \\
\hline 大戟科 Euphorbiaceae & 叶下珠属 Phyllanthus & 2 & 2 \\
\hline 大戟科 Euphorbiaceae & 蓖麻属 Ricinus & 2 & 6 \\
\hline 大戟科 Euphorbiaceae & 乌柏属 Sapium & 2 & 2 \\
\hline 大载科 Euphorbiaceae & 地构叶属 Speranskia & 2 & 15 \\
\hline 大戟科 Euphorbiaceae & 宿莒木属 Strophioblachia & 2 & 7 \\
\hline 大戟科 Euphorbiaceae & 油桐属 Vernicia & 2 & 14 \\
\hline 蝶形花科 Fabaceae & 相思子属 Abrus & 1 & 2 \\
\hline 蝶形花科 Fabaceae & 合萌属 Aeschynomene & 1 & 2 \\
\hline 蝶形花科 Fabaceae & 链荚豆属 Alysicarpus & 1 & 4 \\
\hline 蝶形花科 Fabaceae & 紫穗槐属 Amorpha & 1 & 9 \\
\hline 蝶形花科 Fabaceae & 两型豆属 Amphicarpaea & 1 & 9 \\
\hline 蝶形花科 Fabaceae & 土臬儿属 Apios & 1 & 9 \\
\hline 蝶形花科 Fabaceae & 黄耆属 Astragalus & 1 & 1 \\
\hline 蝶形花科 Fabaceae & 木豆属 Cajanus & 1 & 6 \\
\hline 蝶形花科 Fabaceae & 杭子梢属 Campylotropis & 1 & 11 \\
\hline 蝶形花科 Fabaceae & 锦鸡儿属 Caragana & 1 & 11 \\
\hline 蝶形花科 Fabaceae & 蝙蝠草属 Christia & 1 & 5 \\
\hline 蝶形花科 Fabaceae & 香槐属 Cladrastis & 1 & 9 \\
\hline 蝶形花科 Fabaceae & 旋花豆属 Cochlianthus & 1 & $14(\mathrm{SH})$ \\
\hline 蝶形花科 Fabaceae & 舞草属 Codariocalyx & 1 & 5 \\
\hline 蝶形花科 Fabaceae & 猪屎豆属 Crotalaria & 1 & 2 \\
\hline
\end{tabular}




\begin{tabular}{|c|c|c|c|}
\hline 科 Family & 属 Genus & $\begin{array}{l}\text { 科分布区类型 } \\
\text { Family area types }\end{array}$ & $\begin{array}{l}\text { 属分布区类型 } \\
\text { Genus area types }\end{array}$ \\
\hline 蝶形花科 Fabaceae & 黄檀属 Dalbergia & 1 & 2 \\
\hline 蝶形花科 Fabaceae & 假木豆属 Dendrolobium & 1 & 5 \\
\hline 蝶形花科 Fabaceae & 鱼藤属 Derris & 1 & 2 \\
\hline 蝶形花科 Fabaceae & 山蚂蝗属 Desmodium & 1 & 9 \\
\hline 蝶形花科 Fabaceae & 山黑豆属 Dumasia & 1 & 4 \\
\hline 蝶形花科 Fabaceae & 刺桐属 Erythrina & 1 & 2 \\
\hline 蝶形花科 Fabaceae & 千斤拔属 Flemingia & 1 & 4 \\
\hline 蝶形花科 Fabaceae & 大豆属 Glycine & 1 & 5 \\
\hline 蝶形花科 Fabaceae & 岩黄著属 Hedysarum & 1 & 8 \\
\hline 蝶形花科 Fabaceae & 木蓝属 Indigofera & 1 & 2 \\
\hline 蝶形花科 Fabaceae & 鸡眼草属 Kummerowia & 1 & 9 \\
\hline 蝶形花科 Fabaceae & 山黧豆属 Lathyrus & 1 & 8 \\
\hline 蝶形花科 Fabaceae & 胡枝子属 Lespedeza & 1 & 9 \\
\hline 蝶形花科 Fabaceae & 百脉根属 Lotus & 1 & 10 \\
\hline 蝶形花科 Fabaceae & 马鞍树属 Maackia & 1 & $14(\mathrm{SJ})$ \\
\hline 蝶形花科 Fabaceae & 大翼豆属 Macroptilium & 1 & 3 \\
\hline 蝶形花科 Fabaceae & 苜宿属 Medicago & 1 & 10 \\
\hline 蝶形花科 Fabaceae & 草木犀属 Melilotus & 1 & 10 \\
\hline 蝶形花科 Fabaceae & 崖豆藤属 Millettia & 1 & 2 \\
\hline 蝶形花科 Fabaceae & 黧豆属 Mucuna & 1 & 2 \\
\hline 蝶形花科 Fabaceae & 豆薯属 Pachyrhizus & 1 & 3 \\
\hline 蝶形花科 Fabaceae & 紫雀花属 Parochetus & 1 & 6 \\
\hline 蝶形花科 Fabaceae & 菜豆属 Phaseolus & 1 & 3 \\
\hline 蝶形花科 Fabaceae & 排钱树属 Phyllodium & 1 & 5 \\
\hline 蝶形花科 Fabaceae & 长柄山蚂蝗属 Podocarpium & 1 & 9 \\
\hline 蝶形花科 Fabaceae & 葛属 Pueraria & 1 & 7 \\
\hline 蝶形花科 Fabaceae & 鹿藿属 Rhynchosia & 1 & 2 \\
\hline 蝶形花科 Fabaceae & 田菁属 Sesbania & 1 & 2 \\
\hline 蝶形花科 Fabaceae & 宿苞豆属 Shuteria & 1 & 7 \\
\hline 蝶形花科 Fabaceae & 槐属 Sophora & 1 & 1 \\
\hline 蝶形花科 Fabaceae & 笔花豆属 Stylosanthes & 1 & 2 \\
\hline 蝶形花科 Fabaceae & 灰毛豆属 Tephrosia & 1 & 2 \\
\hline 蝶形花科 Fabaceae & 高山豆属 Tibetia & 1 & $14(\mathrm{SH})$ \\
\hline 蝶形花科 Fabaceae & 车轴草属 Trifolium & 1 & 8 \\
\hline 蝶形花科 Fabaceae & 狸尾豆属 Uraria & 1 & 4 \\
\hline 蝶形花科 Fabaceae & 野踠豆属 Vicia & 1 & 8 \\
\hline 蝶形花科 Fabaceae & 豇豆属 Vigna & 1 & 2 \\
\hline 蝶形花科 Fabaceae & 紫藤属 Wisteria & 1 & 9 \\
\hline 蝶形花科 Fabaceae & 丁癸草属 Zornia & 1 & 2 \\
\hline 壳斗科 Fagaceae & 栗属 Castanea & 8 & 8 \\
\hline 壳斗科 Fagaceae & 雉属 Castanopsis & 8 & 9 \\
\hline
\end{tabular}




\begin{tabular}{|c|c|c|c|}
\hline 科 Family & 属 Genus & $\begin{array}{l}\text { 科分布区类型 } \\
\text { Family area types }\end{array}$ & $\begin{array}{l}\text { 属分布区类型 } \\
\text { Genus area types }\end{array}$ \\
\hline 壳斗科 Fagaceae & 青冈属 Cyclobalanopsis & 8 & 7 \\
\hline 壳斗科 Fagaceae & 柯属 Lithocarpus & 8 & 9 \\
\hline 壳斗科 Fagaceae & 栋属 Quercus & 8 & 8 \\
\hline 大风子科 Flacourtiaceae & 枙子皮属 Itoa & 2 & 7 \\
\hline 大风子科 Flacourtiaceae & 柞木属 Xylosma & 2 & 2 \\
\hline 龙胆科 Gentianaceae & 蔓龙胆属 Crawfurdia & 1 & $14(\mathrm{SH})$ \\
\hline 龙胆科 Gentianaceae & 藻百年属 Exacum & 1 & 4 \\
\hline 龙胆科 Gentianaceae & 龙胆属 Gentiana & 1 & 1 \\
\hline 龙胆科 Gentianaceae & 花针属 Halenia & 1 & 8 \\
\hline 龙胆科 Gentianaceae & 獐牙菜属 Swertia & 1 & 8 \\
\hline 龙胆科 Gentianaceae & 双蝴蝶属 Tripterospermum & 1 & 14 \\
\hline 陇牛儿苗科 Geraniaceae & 陇牛儿苗属 Erodium & 8 & 12 \\
\hline 陇牛儿苗科 Geraniaceae & 老鹳草属 Geranium & 8 & 1 \\
\hline 苦亘苔科 Gesneriaceae & 旋蒴亘苔属 Boea & 3 & 5 \\
\hline 苦苗苔科 Gesneriaceae & 唇柱芭苔属 Chirita & 3 & 7 \\
\hline 苦芭苔科 Gesneriaceae & 苦芭苔属 Conandron & 3 & $14(\mathrm{SJ})$ \\
\hline 苦芭苔科 Gesneriaceae & 珊瑚菅苔属 Corallodiscus & 3 & $14(\mathrm{SH})$ \\
\hline 苦亘苔科 Gesneriaceae & 金盏芭苔属 Isometrum & 3 & 15 \\
\hline 苦芭苔科 Gesneriaceae & 吊石苣苔属 Lysionotus & 3 & 14 \\
\hline 苦亘苔科 Gesneriaceae & 喜鹊芭苔属 Ornithoboea & 3 & 7 \\
\hline 苦亘苔科 Gesneriaceae & 蛛毛草苔属 Paraboea & 3 & 7 \\
\hline 苦芭苔科 Gesneriaceae & 石蝴蝶属 Petrocosmea & 3 & 7 \\
\hline 禾本科 Gramineae & 芨芨草属 Achnatherum & 1 & 10 \\
\hline 禾本科 Gramineae & 尖稃草属 Acrachne & 1 & 4 \\
\hline 禾本科 Gramineae & 剪股颖属 Agrostis & 1 & 1 \\
\hline 禾本科 Gramineae & 须芒草属 Andropogon & 1 & 2 \\
\hline 禾本科 Gramineae & 水蔗草属 Apluda & 1 & 7 \\
\hline 禾本科 Gramineae & 三芒草属 Aristida & 1 & 2 \\
\hline 禾本科 Gramineae & 荩草属 Arthraxon & 1 & 4 \\
\hline 禾本科 Gramineae & 野古草属 Arundinella & 1 & 2 \\
\hline 禾本科 Gramineae & 芦竹属 Arundo & 1 & 10 \\
\hline 禾本科 Gramineae & 燕麦属 Avena & 1 & 10 \\
\hline 禾本科 Gramineae & 地毯草属 Axonopus & 1 & 2 \\
\hline 禾本科 Gramineae & 簕竹属 Bambusa & 1 & 4 \\
\hline 禾本科 Gramineae & 孔颖草属 Bothriochloa & 1 & 2 \\
\hline 禾本科 Gramineae & 臂形草属 Brachiaria & 1 & 2 \\
\hline 禾本科 Gramineae & 雀麦属 Bromus & 1 & 8 \\
\hline 禾本科 Gramineae & 拂子茅属 Calamagrostis & 1 & 8 \\
\hline 禾本科 Gramineae & 细柄草属 Capillipedium & 1 & 4 \\
\hline 禾本科 Gramineae & 酸模芒属 Centotheca & 1 & 4 \\
\hline 禾本科 Gramineae & 空竹属 Cephalostachyum & 1 & 7 \\
\hline
\end{tabular}




\begin{tabular}{|c|c|c|c|}
\hline 科 Family & 属 Genus & $\begin{array}{l}\text { 科分布区类型 } \\
\text { Family area types }\end{array}$ & $\begin{array}{l}\text { 属分布区类型 } \\
\text { Genus area types }\end{array}$ \\
\hline 禾本科 Gramineae & 虎尾草属 Chloris & 1 & 2 \\
\hline 禾本科 Gramineae & 金须茅属 Chrysopogon & 1 & 2 \\
\hline 禾本科 Gramineae & 香茅属 Cymbopogon & 1 & 4 \\
\hline 禾本科 Gramineae & 狗牙根属 Cynodon & 1 & 2 \\
\hline 禾本科 Gramineae & 弓果㯟属 Cyrtococcum & 1 & 4 \\
\hline 禾本科 Gramineae & 龙爪茅属 Dactyloctenium & 1 & 2 \\
\hline 禾本科 Gramineae & 牡竹属 Dendrocalamus & 1 & 7 \\
\hline 禾本科 Gramineae & 野青茅属 Deyeuxia & 1 & 8 \\
\hline 禾本科 Gramineae & 双药芒属 Diandranthus & 1 & $14(\mathrm{SH})$ \\
\hline 禾本科 Gramineae & 双花草属 Dichanthium & 1 & 4 \\
\hline 禾本科 Gramineae & 马唐属 Digitaria & 1 & 2 \\
\hline 禾本科 Gramineae & 油芒属 Eccoilopus & 1 & 14 \\
\hline 禾本科 Gramineae & 稗属 Echinochloa & 1 & 2 \\
\hline 禾本科 Gramineae & 穇属 Eleusine & 1 & 2 \\
\hline 禾本科 Gramineae & 肠须草属 Enteropogon & 1 & 2 \\
\hline 禾本科 Gramineae & 画眉草属 Eragrostis & 1 & 2 \\
\hline 禾本科 Gramineae & 蜈蚣草属 Eremochloa & 1 & 5 \\
\hline 禾本科 Gramineae & 旱茅属 Eremopogon & 1 & 12 \\
\hline 禾本科 Gramineae & 蔗茅属 Erianthus & 1 & 2 \\
\hline 禾本科 Gramineae & 野乘属 Eriochloa & 1 & 2 \\
\hline 禾本科 Gramineae & 黄金茅属 Eulalia & 1 & 4 \\
\hline 禾本科 Gramineae & 拟金茅属 Eulaliopsis & 1 & 7 \\
\hline 禾本科 Gramineae & 箭竹属 Fargesia & 1 & $14(\mathrm{SH})$ \\
\hline 禾本科 Gramineae & 羊茅属 Festuca & 1 & 1 \\
\hline 禾本科 Gramineae & 球穗草属 Hackelochloa & 1 & 2 \\
\hline 禾本科 Gramineae & 镰稃草属 Harpachne & 1 & 6 \\
\hline 禾本科 Gramineae & 牛鞭草属 Hemarthria & 1 & 4 \\
\hline 禾本科 Gramineae & 黄茅属 Heteropogon & 1 & 2 \\
\hline 禾本科 Gramineae & 大麦属 Hordeum & 1 & 8 \\
\hline 禾本科 Gramineae & 苍茅属 Hyparrhenia & 1 & 2 \\
\hline 禾本科 Gramineae & 白茅属 Imperata & 1 & 2 \\
\hline 禾本科 Gramineae & 柳叶箬属 Isachne & 1 & 2 \\
\hline 禾本科 Gramineae & 鸭嘴草属 Ischaemum & 1 & 2 \\
\hline 禾本科 Gramineae & 千金子属 Leptochloa & 1 & 2 \\
\hline 禾本科 Gramineae & 黑麦草属 Lolium & 1 & 10 \\
\hline 禾本科 Gramineae & 淡竹叶属 Lophatherum & 1 & 5 \\
\hline 禾本科 Gramineae & 小草属 Microchloa & 1 & 2 \\
\hline 禾本科 Gramineae & 莠竹属 Microstegium & 1 & 6 \\
\hline 禾本科 Gramineae & 芒属 Miscanthus & 1 & 6 \\
\hline 禾本科 Gramineae & 慈竹属 Neosinocalamus & 1 & 15 \\
\hline 禾本科 Gramineae & 类芦属 Neyraudia & 1 & 4 \\
\hline
\end{tabular}




\begin{tabular}{|c|c|c|c|}
\hline 科 Family & 属 Genus & $\begin{array}{l}\text { 科分布区类型 } \\
\text { Family area types }\end{array}$ & $\begin{array}{l}\text { 属分布区类型 } \\
\text { Genus area types }\end{array}$ \\
\hline 禾本科 Gramineae & 求米草属 Oplismenus & 1 & 2 \\
\hline 禾本科 Gramineae & 稻属 Oryza & 1 & 2 \\
\hline 禾本科 Gramineae & 㯟属 Panicum & 1 & 2 \\
\hline 禾本科 Gramineae & 类雀稗属 Paspalidium & 1 & 2 \\
\hline 禾本科 Gramineae & 雀稗属 Paspalum & 1 & 2 \\
\hline 禾本科 Gramineae & 狼尾草属 Pennisetum & 1 & 2 \\
\hline 禾本科 Gramineae & 茅根属 Perotis & 1 & 4 \\
\hline 禾本科 Gramineae & 显子草属 Phaenosperma & 1 & $14(\mathrm{SJ})$ \\
\hline 禾本科 Gramineae & 芦苇属 Phragmites & 1 & 2 \\
\hline 禾本科 Gramineae & 刚竹属 Phyllostachys & 1 & 14 \\
\hline 禾本科 Gramineae & 早熟禾属 Poa & 1 & 1 \\
\hline 禾本科 Gramineae & 金发草属 Pogonatherum & 1 & 7 \\
\hline 禾本科 Gramineae & 棒头草属 Polypogon & 1 & 8 \\
\hline 禾本科 Gramineae & 假金发草属 Pseudopogonatherum & 1 & 5 \\
\hline 禾本科 Gramineae & 碱茅属 Puccinellia & 1 & 8 \\
\hline 禾本科 Gramineae & 我观草属 Roegneria & 1 & 8 \\
\hline 禾本科 Gramineae & 筒轴茅属 Rottboellia & 1 & 6 \\
\hline 禾本科 Gramineae & 甘蔗属 Saccharum & 1 & 2 \\
\hline 禾本科 Gramineae & 囊颖草属 Sacciolepis & 1 & 2 \\
\hline 禾本科 Gramineae & 裂稃草属 Schizachyrium & 1 & 2 \\
\hline 禾本科 Gramineae & 狗尾草属 Setaria & 1 & 2 \\
\hline 禾本科 Gramineae & 高粱属 Sorghum & 1 & 2 \\
\hline 禾本科 Gramineae & 大油芒属 Spodiopogon & 1 & 11 \\
\hline 禾本科 Gramineae & 鼠尾粟属 Sporobolus & 1 & 2 \\
\hline 禾本科 Gramineae & 针茅属 Stipa & 1 & 8 \\
\hline 禾本科 Gramineae & 菅属 Themeda & 1 & 4 \\
\hline 禾本科 Gramineae & 锋芒草属 Tragus & 1 & 2 \\
\hline 禾本科 Gramineae & 草沙蚕属 Tripogon & 1 & 2 \\
\hline 禾本科 Gramineae & 三毛草属 Trisetum & 1 & 8 \\
\hline 禾本科 Gramineae & 小麦属 Triticum & 1 & 12 \\
\hline 禾本科 Gramineae & 尾稃草属 Urochloa & 1 & 4 \\
\hline 禾本科 Gramineae & 玉山竹属 Yushania & 1 & $14(\mathrm{SH})$ \\
\hline 禾本科 Gramineae & 玉蜀㯟属 Zea & 1 & 3 \\
\hline 藤黄科 Guttiferae & 藤黄属 Garcinia & 2 & 6 \\
\hline 藤黄科 Guttiferae & 金丝桃属 Hypericum & 2 & 1 \\
\hline 小二仙草科 Haloragidaceae & 狐尾藻属 Myriophyllum & 1 & 1 \\
\hline 金缕梅科 Hamamelidaceae & 聯木属 Loropetalum & 8 & 14 \\
\hline 莲叶桐科 Hernandiaceae & 青藤属 Illigera & 2 & 6 \\
\hline 水鳖科 Hydrocharitaceae & 水鳖属 Hydrocharis & 1 & 4 \\
\hline 水鳖科 Hydrocharitaceae & 苦草属 Vallisneria & 1 & 2 \\
\hline 茶荣英科 Icacinaceae & 假海桐属 Pittosporopsis & 2 & 7 \\
\hline
\end{tabular}




\begin{tabular}{|c|c|c|c|}
\hline 科 Family & 属 Genus & $\begin{array}{l}\text { 科分布区类型 } \\
\text { Family area types }\end{array}$ & $\begin{array}{l}\text { 属分布区类型 } \\
\text { Genus area types }\end{array}$ \\
\hline 凬尾科 Iridaceae & 射干属 Belamcanda & 2 & 14 \\
\hline 煘尾科 Iridaceae & 唐菖蒲属 Gladiolus & 2 & 12 \\
\hline 荅尾科 Iridaceae & 鸢尾属 Iris & 2 & 8 \\
\hline 荅尾科 Iridaceae & 虎皮花属 Tigridia & 2 & 3 \\
\hline 胡桃科 Juglandaceae & 山核桃属 Carya & 8 & 9 \\
\hline 胡桃科 Juglandaceae & 黄杞属 Engelhardtia & 8 & 8 \\
\hline 胡桃科 Juglandaceae & 胡桃属 Juglans & 8 & 8 \\
\hline 胡桃科 Juglandaceae & 化香树属 Platycarya & 8 & $14(\mathrm{SJ})$ \\
\hline 胡桃科 Juglandaceae & 枫杨属 Pterocarya & 8 & 11 \\
\hline 灯心草科 Juncaceae & 灯心草属 Juncus & 8 & 1 \\
\hline 唇形科 Labiatae & 筋骨草属 Ajuga & 1 & 10 \\
\hline 唇形科 Labiatae & 水棘针属 Amethystea & 1 & 11 \\
\hline 唇形科 Labiatae & 风轮菜属 Clinopodium & 1 & 8 \\
\hline 唇形科 Labiatae & 羽萝木属 Colebrookea & 1 & 7 \\
\hline 唇形科 Labiatae & 火把花属 Colquhounia & 1 & $14(\mathrm{SH})$ \\
\hline 唇形科 Labiatae & 簇序草属 Craniotome & 1 & $14(\mathrm{SH})$ \\
\hline 唇形科 Labiatae & 香蔏属 Elsholtzia & 1 & 10 \\
\hline 唇形科 Labiatae & 广防风属 Epimeredi & 1 & 5 \\
\hline 唇形科 Labiatae & 网萼木属 Geniosporum & 1 & 6 \\
\hline 唇形科 Labiatae & 雉花属 Gomphostemma & 1 & 7 \\
\hline 唇形科 Labiatae & 夏至草属 Lagopsis & 1 & 10 \\
\hline 唇形科 Labiatae & 益母草属 Leonurus & 1 & 10 \\
\hline 唇形科 Labiatae & 绣球防风属 Leucas & 1 & 4 \\
\hline 唇形科 Labiatae & 米团花属 Leucosceptrum & 1 & $14(\mathrm{SH})$ \\
\hline 唇形科 Labiatae & 地笋属 Lycopus & 1 & 8 \\
\hline 唇形科 Labiatae & 龙头草属 Meehania & 1 & 9 \\
\hline 唇形科 Labiatae & 蜜蜂花属 Melissa & 1 & 10 \\
\hline 唇形科 Labiatae & 薄荷属 Mentha & 1 & 8 \\
\hline 唇形科 Labiatae & 冠唇花属 Microtoena & 1 & 7 \\
\hline 唇形科 Labiatae & 石荠草属 Mosla & 1 & 7 \\
\hline 唇形科 Labiatae & 荆芥属 Nepeta & 1 & 10 \\
\hline 唇形科 Labiatae & 钩萝草属 Notochaete & 1 & $14(\mathrm{SH})$ \\
\hline 唇形科 Labiatae & 罗勒属 Ocimum & 1 & 2 \\
\hline 唇形科 Labiatae & 牛至属 Origanum & 1 & 10 \\
\hline 唇形科 Labiatae & 鸡脚参属 Orthosiphon & 1 & 4 \\
\hline 唇形科 Labiatae & 假粘苏属 Paraphlomis & 1 & 7 \\
\hline 唇形科 Labiatae & 紫苏属 Perilla & 1 & 14 \\
\hline 唇形科 Labiatae & 糙苏属 Phlomis & 1 & 10 \\
\hline 唇形科 Labiatae & 夏枯草属 Prunella & 1 & 8 \\
\hline 唇形科 Labiatae & 香茶菜属 Rabdosia & 1 & 4 \\
\hline 唇形科 Labiatae & 鼠尾草属 Salvia & 1 & 1 \\
\hline
\end{tabular}




\begin{tabular}{|c|c|c|c|}
\hline 科 Family & 属 Genus & $\begin{array}{l}\text { 科分布区类型 } \\
\text { Family area types }\end{array}$ & $\begin{array}{l}\text { 属分布区类型 } \\
\text { Genus area types }\end{array}$ \\
\hline 唇形科 Labiatae & 裂叶荆芥属 Schizonepeta & 1 & 11 \\
\hline 唇形科 Labiatae & 黄芩属 Scutellaria & 1 & 1 \\
\hline 唇形科 Labiatae & 水苏属 Stachys & 1 & 1 \\
\hline 唇形科 Labiatae & 香科科属 Teucrium & 1 & 8 \\
\hline 唇形科 Labiatae & 百里香属 Thymus & 1 & 10 \\
\hline 木通科 Lardizabalaceae & 木通属 Akebia & 3 & $14(\mathrm{SJ})$ \\
\hline 木通科 Lardizabalaceae & 八月瓜属 Holboellia & 3 & $14(\mathrm{SH})$ \\
\hline 樟科 Lauraceae & 樟属 Cinnamomum & 2 & 3 \\
\hline 樟科 Lauraceae & 山胡椒属 Lindera & 2 & 9 \\
\hline 樟科 Lauraceae & 木姜子属 Litsea & 2 & 3 \\
\hline 樟科 Lauraceae & 润楠属 Machilus & 2 & 7 \\
\hline 樟科 Lauraceae & 新樟属 Neocinnamomum & 2 & 7 \\
\hline 樟科 Lauraceae & 楠属 Phoebe & 2 & 7 \\
\hline 樟科 Lauraceae & 檫木属 Sassafras & 2 & 9 \\
\hline 浮萍科 Lemnaceae & 浮萍属 Lemna & 1 & 1 \\
\hline 狸藻科 Lentibulariaceae & 狸藻属 Utricularia & 1 & 1 \\
\hline 百合科 Liliaceae & 粉条儿菜属 Aletris & 8 & 9 \\
\hline 百合科 Liliaceae & 苟属 Allium & 8 & 8 \\
\hline 百合科 Liliaceae & 天门冬属 Asparagus & 8 & 4 \\
\hline 百合科 Liliaceae & 万寿竹属 Disporum & 8 & 14 \\
\hline 百合科 Liliaceae & 鹭畾草属 Diuranthera & 8 & 15 \\
\hline 百合科 Liliaceae & 萱草属 Hemerocallis & 8 & 10 \\
\hline 百合科 Liliaceae & 百合属 Lilium & 8 & 8 \\
\hline 百合科 Liliaceae & 山麦冬属 Liriope & 8 & $14(\mathrm{SJ})$ \\
\hline 百合科 Liliaceae & 沿阶草属 Ophiopogon & 8 & 14 \\
\hline 百合科 Liliaceae & 重楼属 Paris & 8 & 10 \\
\hline 百合科 Liliaceae & 黄精属 Polygonatum & 8 & 8 \\
\hline 百合科 Liliaceae & 吉祥草属 Reineckia & 8 & $14(\mathrm{SJ})$ \\
\hline 百合科 Liliaceae & 万年青属 Rohdea & 8 & $14(\mathrm{SJ})$ \\
\hline 百合科 Liliaceae & 鹿药属 Smilacina & 8 & 9 \\
\hline 百合科 Liliaceae & 藜芦属 Veratrum & 8 & 8 \\
\hline 亚麻科 Linaceae & 亚麻属 Linum & 8 & 8 \\
\hline 亚麻科 Linaceae & 石海椒属 Reinwardtia & 8 & $14(\mathrm{SH})$ \\
\hline 马钱科 Loganiaceae & 马钱属 Strychnos & 5 & 2 \\
\hline 桑寄生科 Loranthaceae & 桑寄生属 Loranthus & 2 & 10 \\
\hline 桑寄生科 Loranthaceae & 鞘花属 Macrosolen & 2 & 7 \\
\hline 桑寄生科 Loranthaceae & 钝果寄生属 Taxillus & 2 & 7 \\
\hline 千屈菜科 Lythraceae & 紫薇属 Lagerstroemia & 1 & 5 \\
\hline 千屈菜科 Lythraceae & 千屈菜属 Lythrum & 1 & 1 \\
\hline 千屈菜科 Lythraceae & 虾子花属 Woodfordia & 1 & 6 \\
\hline 木兰科 Magnoliaceae & 木兰属 Magnolia & 9 & 9 \\
\hline
\end{tabular}




\begin{tabular}{|c|c|c|c|}
\hline 科 Family & 属 Genus & $\begin{array}{l}\text { 科分布区类型 } \\
\text { Family area types }\end{array}$ & $\begin{array}{l}\text { 属分布区类型 } \\
\text { Genus area types }\end{array}$ \\
\hline 木兰科 Magnoliaceae & 含笑属 Michelia & 9 & 7 \\
\hline 锦葵科 Malvaceae & 秋葵属 Abelmoschus & 2 & 4 \\
\hline 锦葵科 Malvaceae & 苟麻属 Abutilon & 2 & 2 \\
\hline 锦葵科 Malvaceae & 棉属 Gossypium & 2 & 2 \\
\hline 锦葵科 Malvaceae & 木槿属 Hibiscus & 2 & 2 \\
\hline 锦葵科 Malvaceae & 锦葵属 Malva & 2 & 10 \\
\hline 锦葵科 Malvaceae & 赛葵属 Malvastrum & 2 & 3 \\
\hline 锦葵科 Malvaceae & 黄花稔属 Sida & 2 & 2 \\
\hline 锦葵科 Malvaceae & 梵天花属 Urena & 2 & 2 \\
\hline 野牡丹科 Melastomataceae & 野牡丹属 Melastoma & 2 & 5 \\
\hline 野牡丹科 Melastomataceae & 金锦香属 Osbeckia & 2 & 4 \\
\hline 野牡丹科 Melastomataceae & 尖子木属 Oxyspora & 2 & 7 \\
\hline 野牡丹科 Melastomataceae & 锦香草属 Phyllagathis & 2 & 7 \\
\hline 楝科 Meliaceae & 浆果楝属 Cipadessa & 2 & 7 \\
\hline 楝科 Meliaceae & 楝属 Melia & 2 & 4 \\
\hline 楝科 Meliaceae & 地黄连属 Munronia & 2 & 7 \\
\hline 楝科 Meliaceae & 香椿属 Toona & 2 & 5 \\
\hline 防己科 Menispermaceae & 木防己属 Cocculus & 2 & 2 \\
\hline 防已科 Menispermaceae & 轮环藤属 Cyclea & 2 & 7 \\
\hline 防己科 Menispermaceae & 蝙蝠葛属 Menispermum & 2 & 9 \\
\hline 防已科 Menispermaceae & 细圆藤属 Pericampylus & 2 & 7 \\
\hline 防已科 Menispermaceae & 风龙属 Sinomenium & 2 & $14(\mathrm{SJ})$ \\
\hline 防已科 Menispermaceae & 千金藤属 Stephania & 2 & 4 \\
\hline 含羞草科 Mimosaceae & 金合欢属 Acacia & 2 & 2 \\
\hline 含羞草科 Mimosaceae & 合欢属 Albizia & 2 & 2 \\
\hline 含羞草科 Mimosaceae & 棋子豆属 Cylindrokelupha & 2 & 5 \\
\hline 含羞草科 Mimosaceae & 银合欢属 Leucaena & 2 & 2 \\
\hline 含羞草科 Mimosaceae & 含差草属 Mimosa & 2 & 2 \\
\hline 含羞草科 Mimosaceae & 假含羞草属 Neptunia & 2 & 2 \\
\hline 含羞草科 Mimosaceae & 牧豆树属 Prosopis & 2 & 2 \\
\hline 桑科 Moraceae & 构属 Broussonetia & 1 & 7 \\
\hline 桑科 Moraceae & 柘属 Cudrania & 1 & 5 \\
\hline 桑科 Moraceae & 水蛇麻属 Fatoua & 1 & 4 \\
\hline 桑科 Moraceae & 榕属 Ficus & 1 & 2 \\
\hline 桑科 Moraceae & 葎草属 Humulus & 1 & 8 \\
\hline 桑科 Moraceae & 桑属 Morus & 1 & 8 \\
\hline 芭蕉科 Musaceae & 芭蕉属 Musa & 4 & 5 \\
\hline 芭蕉科 Musaceae & 地涌金莲属 Musella & 4 & 15 \\
\hline 杨梅科 Myricaceae & 杨梅属 Myrica & 1 & 8 \\
\hline 紫金牛科 Myrsinaceae & 紫金牛属 Ardisia & 2 & 2 \\
\hline 紫金牛科 Myrsinaceae & 杜茎山属 Maesa & 2 & 4 \\
\hline
\end{tabular}




\begin{tabular}{|c|c|c|c|}
\hline 科 Family & 属 Genus & $\begin{array}{l}\text { 科分布区类型 } \\
\text { Family area types }\end{array}$ & $\begin{array}{l}\text { 属分布区类型 } \\
\text { Genus area types }\end{array}$ \\
\hline 紫金牛科 Myrsinaceae & 铁仔属 Myrsine & 2 & 6 \\
\hline 紫金牛科 Myrsinaceae & 密花树属 Rapanea & 2 & 2 \\
\hline 桃金娘科 Myrtaceae & 桉属 Eucalyptus & 2 & 5 \\
\hline 桃金娘科 Myrtaceae & 番石榴属 Psidium & 2 & 3 \\
\hline 桃金娘科 Myrtaceae & 蒲桃属 Syzygium & 2 & 4 \\
\hline 紫茉莉科 Nyctaginaceae & 黄细心属 Boerhavia & 3 & 2 \\
\hline 紫茉莉科 Nyctaginaceae & 叶子花属 Bougainvillea & 3 & 3 \\
\hline 紫茉莉科 Nyctaginaceae & 粘腺果属 Commicarpus & 3 & 2 \\
\hline 紫茉莉科 Nyctaginaceae & 紫茉莉属 Mirabilis & 3 & 3 \\
\hline 蓝果树科 Nyssaceae & 喜树属 Camptotheca & 9 & 15 \\
\hline 木犀科 Oleaceae & 流苏树属 Chionanthus & 1 & 9 \\
\hline 木犀科 Oleaceae & 梣属 Fraxinus & 1 & 8 \\
\hline 木犀科 Oleaceae & 素馨属 Jasminum & 1 & 2 \\
\hline 木犀科 Oleaceae & 女贞属 Ligustrum & 1 & 10 \\
\hline 木犀科 Oleaceae & 木犀榄属 Olea & 1 & 12 \\
\hline 木犀科 Oleaceae & 木犀属 Osmanthus & 1 & 9 \\
\hline 木犀科 Oleaceae & 丁香属 Syringa & 1 & 10 \\
\hline 柳叶菜科 Onagraceae & 露珠草属 Circaea & 1 & 8 \\
\hline 柳叶菜科 Onagraceae & 柳叶菜属 Epilobium & 1 & 8 \\
\hline 柳叶菜科 Onagraceae & 丁香苶属 Ludwigia & 1 & 2 \\
\hline 柳叶菜科 Onagraceae & 月见草属 Oenothera & 1 & 3 \\
\hline 兰科 Orchidaceae & 开唇兰属 Anoectochilus & 1 & 5 \\
\hline 兰科 Orchidaceae & 白及属 Bletilla & 1 & 14 \\
\hline 兰科 Orchidaceae & 虾脊兰属 Calanthe & 1 & 2 \\
\hline 兰科 Orchidaceae & 兰属 Cymbidium & 1 & 5 \\
\hline 兰科 Orchidaceae & 蛇舌兰属 Diploprora & 1 & 7 \\
\hline 兰科 Orchidaceae & 火烧兰属 Epipactis & 1 & 8 \\
\hline 兰科 Orchidaceae & 地宝兰属 Geodorum & 1 & 4 \\
\hline 兰科 Orchidaceae & 玉凤花属 Habenaria & 1 & 8 \\
\hline 兰科 Orchidaceae & 芋兰属 Nervilia & 1 & 4 \\
\hline 兰科 Orchidaceae & 红门兰属 Orchis & 1 & 8 \\
\hline 兰科 Orchidaceae & 阔荵兰属 Peristylus & 1 & 5 \\
\hline 兰科 Orchidaceae & 苞舌兰属 Spathoglottis & 1 & 5 \\
\hline 列当科 Orobanchaceae & 列当属 Orobanche & 8 & 8 \\
\hline 酢浆草科 Oxalidaceae & 感应草属 Biophytum & 1 & 2 \\
\hline 酢浆草科 Oxalidaceae & 酢浆草属 Oxalis & 1 & 1 \\
\hline 药药科 Paeoniaceae & 苟药属 Paeonia & 8 & 8 \\
\hline 棕㭣科 Palmae & 油棕属 Elaeis & 2 & 2 \\
\hline 罂粟科 Papaveraceae & 紫堇属 Corydalis & 8 & 8 \\
\hline 䍃粟科 Papaveraceae & 紫金龙属 Dactylicapnos & 8 & $14(\mathrm{SH})$ \\
\hline 罂粟科 Papaveraceae & 秃疮花属 Dicranostigma & 8 & $14(\mathrm{SH})$ \\
\hline
\end{tabular}




\begin{tabular}{|c|c|c|c|}
\hline 科 Family & 属 Genus & $\begin{array}{l}\text { 科分布区类型 } \\
\text { Family area types }\end{array}$ & $\begin{array}{l}\text { 属分布区类型 } \\
\text { Genus area types }\end{array}$ \\
\hline 罂粟科 Papaveraceae & 罂粟属 Papaver & 8 & 8 \\
\hline 西番莲科 Passifloraceae & 西番莲属 Passiflora & 2 & 2 \\
\hline 胡麻科 Pedaliaceae & 胡麻属 Sesamum & 4 & 4 \\
\hline 透骨草科 Phrymaceae & 透骨草属 Phryma & 9 & 9 \\
\hline 商陆科 Phytolaccaceae & 商陆属 Phytolacca & 2 & 2 \\
\hline 胡椒科 Piperaceae & 草胡椒属 Peperomia & 2 & 2 \\
\hline 胡椒科 Piperaceae & 胡椒属 Piper & 2 & 2 \\
\hline 海桐花科 Pittosporaceae & 海桐花属 Pittosporum & 4 & 4 \\
\hline 车前科 Plantaginaceae & 车前属 Plantago & 1 & 1 \\
\hline 白花丹科 Plumbaginaceae & 蓝雪花属 Ceratostigma & 1 & 6 \\
\hline 白花丹科 Plumbaginaceae & 白花丹属 Plumbago & 1 & 2 \\
\hline 远志科 Polygalaceae & 远志属 Polygala & 1 & 1 \\
\hline 苶科 Polygonaceae & 金线草属 Antenoron & 1 & 9 \\
\hline 苶科 Polygonaceae & 养麦属 Fagopyrum & 1 & 10 \\
\hline 蓼科 Polygonaceae & 何首乌属 Fallopia & 1 & 8 \\
\hline 蓼科 Polygonaceae & 山蓼属 Oxyria & 1 & 8 \\
\hline 苶科 Polygonaceae & 苶属 Polygonum & 1 & 8 \\
\hline 苶科 Polygonaceae & 虎杖属 Reynoutria & 1 & 11 \\
\hline 蓼科 Polygonaceae & 酸模属 Rumex & 1 & 1 \\
\hline 马齿苋科 Portulacaceae & 马齿苋属 Portulaca & 1 & 2 \\
\hline 马齿苋科 Portulacaceae & 土人参属 Talinum & 1 & 2 \\
\hline 报春花科 Primulaceae & 点地梅属 Androsace & 1 & 8 \\
\hline 报春花科 Primulaceae & 珍珠菜属 Lysimachia & 1 & 1 \\
\hline 报春花科 Primulaceae & 报春花属 Primula & 1 & 8 \\
\hline 山龙眼科 Proteaceae & 山龙眼属 Helicia & 2 & 5 \\
\hline 鹿蹄草科 Pyrolaceae & 鹿蹄草属 Pyrola & 8 & 8 \\
\hline 毛茛科 Ranunculaceae & 乌头属 Aconitum & 1 & 8 \\
\hline 毛茛科 Ranunculaceae & 类叶升麻属 Actaea & 1 & 8 \\
\hline 毛茛科 Ranunculaceae & 银莲花属 Anemone & 1 & 1 \\
\hline 毛茛科 Ranunculaceae & 耧斗菜属 Aquilegia & 1 & 8 \\
\hline 毛茛科 Ranunculaceae & 水毛茛属 Batrachium & 1 & 8 \\
\hline 毛茛科 Ranunculaceae & 升麻属 Cimicifuga & 1 & 8 \\
\hline 毛茛科 Ranunculaceae & 铁线莲属 Clematis & 1 & 1 \\
\hline 毛茛科 Ranunculaceae & 翠雀属 Delphinium & 1 & 8 \\
\hline 毛茛科 Ranunculaceae & 白头翁属 Pulsatilla & 1 & 8 \\
\hline 毛茛科 Ranunculaceae & 毛茛属 Ranunculus & 1 & 1 \\
\hline 毛莨科 Ranunculaceae & 唐松草属 Thalictrum & 1 & 8 \\
\hline 毛莨科 Ranunculaceae & 金莲花属 Trollius & 1 & 8 \\
\hline 鼠李科 Rhamnaceae & 勾儿茶属 Berchemia & 1 & 9 \\
\hline 鼠李科 Rhamnaceae & 蛇藤属 Colubrina & 1 & 2 \\
\hline 鼠李科 Rhamnaceae & 马甲子属 Paliurus & 1 & 10 \\
\hline
\end{tabular}




\begin{tabular}{|c|c|c|c|}
\hline 科 Family & 属 Genus & $\begin{array}{l}\text { 科分布区类型 } \\
\text { Family area types }\end{array}$ & $\begin{array}{l}\text { 属分布区类型 } \\
\text { Genus area types }\end{array}$ \\
\hline 鼠李科 Rhamnaceae & 猫乳属 Rhamnella & 1 & 5 \\
\hline 鼠李科 Rhamnaceae & 鼠李属 Rhamnus & 1 & 1 \\
\hline 鼠李科 Rhamnaceae & 雀梅藤属 Sageretia & 1 & 3 \\
\hline 鼠李科 Rhamnaceae & 杳属 Ziziphus & 1 & 2 \\
\hline 葍薇科 Rosaceae & 龙芽草属 Agrimonia & 1 & 8 \\
\hline 蔷薇科 Rosaceae & 桃属 Amygdalus & 1 & 10 \\
\hline 菩薇科 Rosaceae & 杏属 Armeniaca & 1 & 11 \\
\hline 蔷薇科 Rosaceae & 樱属 Cerasus & 1 & 8 \\
\hline 葍薇科 Rosaceae & 木瓜属 Chaenomeles & 1 & 14 \\
\hline 薔薇科 Rosaceae & 栒子属 Cotoneaster & 1 & 10 \\
\hline 蓄微科 Rosaceae & 山楂属 Crataegus & 1 & 8 \\
\hline 菩薇科 Rosaceae & 蛇莓属 Duchesnea & 1 & 7 \\
\hline 菩薇科 Rosaceae & 枇杷属 Eriobotrya & 1 & 7 \\
\hline 葍薇科 Rosaceae & 草莓属 Fragaria & 1 & 8 \\
\hline 葍薇科 Rosaceae & 路边青属 Geum & 1 & 8 \\
\hline 菩薇科 Rosaceae & 苹果属 Malus & 1 & 8 \\
\hline 苗薇科 Rosaceae & 绣线梅属 Neillia & 1 & 14 \\
\hline 蓄薇科 Rosaceae & 小石积属 Osteomeles & 1 & 14 \\
\hline 菩薇科 Rosaceae & 石楠属 Photinia & 1 & 9 \\
\hline 蔷薇科 Rosaceae & 委陵菜属 Potentilla & 1 & 8 \\
\hline 葍薇科 Rosaceae & 扁核木属 Prinsepia & 1 & $14(\mathrm{SH})$ \\
\hline 蓄薇科 Rosaceae & 李属 Prunus & 1 & 8 \\
\hline 蓄薇科 Rosaceae & 火棘属 Pyracantha & 1 & 10 \\
\hline 荎薇科 Rosaceae & 梨属 Pyrus & 1 & 10 \\
\hline 蓄薇科 Rosaceae & 石斑木属 Rhaphiolepis & 1 & 7 \\
\hline 蔷薇科 Rosaceae & 蓄薇属 Rosa & 1 & 8 \\
\hline 葍薇科 Rosaceae & 悬钩子属 Rubus & 1 & 1 \\
\hline 蓄薇科 Rosaceae & 山莓草属 Sibbaldia & 1 & 10 \\
\hline 菩薇科 Rosaceae & 花楸属 Sorbus & 1 & 8 \\
\hline 荎薇科 Rosaceae & 绣线菊属 Spiraea & 1 & 8 \\
\hline 茜草科 Rubiaceae & 丰花草属 Borreria & 1 & 2 \\
\hline 茜草科 Rubiaceae & 山石榴属 Catunaregam & 1 & 6 \\
\hline 茜草科 Rubiaceae & 拉拉藤属 Galium & 1 & 1 \\
\hline 茜草科 Rubiaceae & 耳草属 Hedyotis & 1 & 2 \\
\hline 茜草科 Rubiaceae & 须弥茜树属 Himalrandia & 1 & $14(\mathrm{SH})$ \\
\hline 茜草科 Rubiaceae & 土连趐属 Hymenodictyon & 1 & 6 \\
\hline 茜草科 Rubiaceae & 红芽大戟属 Knoxia & 1 & 6 \\
\hline 茜草科 Rubiaceae & 野丁香属 Leptodermis & 1 & 14 \\
\hline 茜草科 Rubiaceae & 滇丁香属 Luculia & 1 & $14(\mathrm{SH})$ \\
\hline 茜草科 Rubiaceae & 玉叶金花属 Mussaenda & 1 & 6 \\
\hline 茜草科 Rubiaceae & 新耳草属 Neanotis & 1 & 5 \\
\hline
\end{tabular}




\begin{tabular}{|c|c|c|c|}
\hline 科 Family & 属 Genus & $\begin{array}{l}\text { 科分布区类型 } \\
\text { Family area types }\end{array}$ & $\begin{array}{l}\text { 属分布区类型 } \\
\text { Genus area types }\end{array}$ \\
\hline 茜草科 Rubiaceae & 蛇根草属 Ophiorrhiza & 1 & 7 \\
\hline 茜草科 Rubiaceae & 鸡矢藤属 Paederia & 1 & 7 \\
\hline 茜草科 Rubiaceae & 大沙叶属 Pavetta & 1 & 4 \\
\hline 茜草科 Rubiaceae & 茜草属 Rubia & 1 & 8 \\
\hline 茜草科 Rubiaceae & 水锦树属 Wendlandia & 1 & 5 \\
\hline 芸香科 Rutaceae & 酒饼簕属 Atalantia & 2 & 5 \\
\hline 芸香科 Rutaceae & 石椒草属 Boenninghausenia & 2 & 7 \\
\hline 芸香科 Rutaceae & 柑橘属 Citrus & 2 & 7 \\
\hline 芸香科 Rutaceae & 黄皮属 Clausena & 2 & 4 \\
\hline 芸香科 Rutaceae & 九里香属 Murraya & 2 & 7 \\
\hline 芸香科 Rutaceae & 芸香属 Ruta & 2 & 10 \\
\hline 芸香科 Rutaceae & 飞龙掌血属 Toddalia & 2 & 6 \\
\hline 芸香科 Rutaceae & 花椒属 Zanthoxylum & 2 & 2 \\
\hline 清风藤科 Sabiaceae & 泡花树属 Meliosma & 7 & 3 \\
\hline 清风藤科 Sabiaceae & 清风藤属 Sabia & 7 & 7 \\
\hline 杨柳科 Salicaceae & 杨属 Populus & 8 & 8 \\
\hline 杨柳科 Salicaceae & 柳属 Salix & 8 & 8 \\
\hline 檀香科 Santalaceae & 沙针属 Osyris & 2 & 12 \\
\hline 檀香科 Santalaceae & 百蒿草属 Thesium & 2 & 4 \\
\hline 无患子科 Sapindaceae & 倒地铃属 Cardiospermum & 2 & 2 \\
\hline 无患子科 Sapindaceae & 茶条木属 Delavaya & 2 & 7 \\
\hline 无患子科 Sapindaceae & 龙眼属 Dimocarpus & 2 & 5 \\
\hline 无患子科 Sapindaceae & 车桑子属 Dodonaea & 2 & 2 \\
\hline 无患子科 Sapindaceae & 奕树属 Koelreuteria & 2 & 15 \\
\hline 无患子科 Sapindaceae & 荔枝属 Litchi & 2 & 7 \\
\hline 无患子科 Sapindaceae & 无患子属 Sapindus & 2 & 3 \\
\hline 三白草科 Saururaceae & 载菜属 Houttuynia & 9 & 14 \\
\hline 三白草科 Saururaceae & 三白草属 Saururus & 9 & 9 \\
\hline 虎耳草科 Saxifragaceae & 落新妇属 Astilbe & 1 & 9 \\
\hline 虎耳草科 Saxifragaceae & 岩白菜属 Bergenia & 1 & 11 \\
\hline 虎耳草科 Saxifragaceae & 赤壁木属 Decumaria & 1 & 9 \\
\hline 虎耳草科 Saxifragaceae & 溲疏属 Deutzia & 1 & 9 \\
\hline 虎耳草科 Saxifragaceae & 常山属 Dichroa & 1 & 7 \\
\hline 虎耳草科 Saxifragaceae & 绣球属 Hydrangea & 1 & 9 \\
\hline 虎耳草科 Saxifragaceae & 梅花草属 Parnassia & 1 & 8 \\
\hline 虎耳草科 Saxifragaceae & 山梅花属 Philadelphus & 1 & 8 \\
\hline 虎耳草科 Saxifragaceae & 茶蔍子属 Ribes & 1 & 8 \\
\hline 虎耳草科 Saxifragaceae & 虎耳草属 Saxifraga & 1 & 8 \\
\hline 五味子科 Schisandraceae & 南五味子属 Kadsura & 9 & 7 \\
\hline 五味子科 Schisandraceae & 五味子属 Schisandra & 9 & 9 \\
\hline 玄参科 Scrophulariaceae & 毛黁香属 Adenosma & 1 & 5 \\
\hline
\end{tabular}




\begin{tabular}{|c|c|c|c|}
\hline 科 Family & 属 Genus & $\begin{array}{l}\text { 科分布区类型 } \\
\text { Family area types }\end{array}$ & $\begin{array}{l}\text { 属分布区类型 } \\
\text { Genus area types }\end{array}$ \\
\hline 玄参科 Scrophulariaceae & 来江藤属 Brandisia & 1 & 7 \\
\hline 玄参科 Scrophulariaceae & 鞭打绣球属 Hemiphragma & 1 & $14(\mathrm{SH})$ \\
\hline 玄参科 Scrophulariaceae & 钟萼草属 Lindenbergia & 1 & 6 \\
\hline 玄参科 Scrophulariaceae & 母草属 Lindernia & 1 & 2 \\
\hline 玄参科 Scrophulariaceae & 通泉草属 Mazus & 1 & 5 \\
\hline 玄参科 Scrophulariaceae & 山罗花属 Melampyrum & 1 & 8 \\
\hline 玄参科 Scrophulariaceae & 沟酸浆属 Mimulus & 1 & 8 \\
\hline 玄参科 Scrophulariaceae & 马先蒿属 Pedicularis & 1 & 8 \\
\hline 玄参科 Scrophulariaceae & 松蒿属 Phtheirospermum & 1 & 14 \\
\hline 玄参科 Scrophulariaceae & 翅茎草属 Pterygiella & 1 & 15 \\
\hline 玄参科 Scrophulariaceae & 野甘草属 Scoparia & 1 & 3 \\
\hline 玄参科 Scrophulariaceae & 阴行草属 Siphonostegia & 1 & 10 \\
\hline 玄参科 Scrophulariaceae & 独脚金属 Striga & 1 & 4 \\
\hline 玄参科 Scrophulariaceae & 蝴蝶草属 Torenia & 1 & 4 \\
\hline 玄参科 Scrophulariaceae & 毛荵花属 Verbascum & 1 & 10 \\
\hline 玄参科 Scrophulariaceae & 婆婆纳属 Veronica & 1 & 8 \\
\hline 玄参科 Scrophulariaceae & 腹水草属 Veronicastrum & 1 & 9 \\
\hline 苦木科 Simaroubaceae & 臭椿属 Ailanthus & 2 & 5 \\
\hline 苦木科 Simaroubaceae & 苦树属 Picrasma & 2 & 3 \\
\hline 菝葜科 Smilacaceae & 肖菝荴属 Heterosmilax & 2 & 7 \\
\hline 菝葜科 Smilacaceae & 菝萑属 Smilax & 2 & 2 \\
\hline 茄科 Solanaceae & 山茛宕属 Anisodus & 1 & $14(\mathrm{SH})$ \\
\hline 茄科 Solanaceae & 地海椒属 Archiphysalis & 1 & $14(\mathrm{SJ})$ \\
\hline 茄科 Solanaceae & 颠茄属 Atropa & 1 & 12 \\
\hline 茄科 Solanaceae & 曼陀罗属 Datura & 1 & 2 \\
\hline 茄科 Solanaceae & 红丝线属 Lycianthes & 1 & 3 \\
\hline 茄科 Solanaceae & 蕃茄属 Lycopersicon & 1 & 3 \\
\hline 茄科 Solanaceae & 假酸浆属 Nicandra & 1 & 3 \\
\hline 茄科 Solanaceae & 酸浆属 Physalis & 1 & 1 \\
\hline 茄科 Solanaceae & 泡囊草属 Physochlaina & 1 & 11 \\
\hline 茄科 Solanaceae & 茄属 Solanum & 1 & 1 \\
\hline 旌节花科 Stachyuraceae & 権节花属 Stachyurus & 14 & 14 \\
\hline 省沽油科 Staphyleaceae & 野鸦椿属 Euscaphis & 3 & $14(\mathrm{SJ})$ \\
\hline 省沽油科 Staphyleaceae & 山香圆属 Turpinia & 3 & 3 \\
\hline 百部科 Stemonaceae & 百部属 Stemona & 5 & 5 \\
\hline 梧桐科 Sterculiaceae & 昂天莲属 Ambroma & 2 & 5 \\
\hline 梧桐科 Sterculiaceae & 刺果藤属 Byttneria & 2 & 2 \\
\hline 梧桐科 Sterculiaceae & 火绳树属 Eriolaena & 2 & 7 \\
\hline 梧桐科 Sterculiaceae & 梧桐属 Firmiana & 2 & $14(\mathrm{SJ})$ \\
\hline 梧桐科 Sterculiaceae & 山芝麻属 Helicteres & 2 & 2 \\
\hline 梧桐科 Sterculiaceae & 梅蓝属 Melhania & 2 & 6 \\
\hline
\end{tabular}




\begin{tabular}{|c|c|c|c|}
\hline 科 Family & 属 Genus & $\begin{array}{l}\text { 科分布区类型 } \\
\text { Family area types }\end{array}$ & $\begin{array}{l}\text { 属分布区类型 } \\
\text { Genus area types }\end{array}$ \\
\hline 梧桐科 Sterculiaceae & 马松子属 Melochia & 2 & 2 \\
\hline 梧桐科 Sterculiaceae & 翅子树属 Pterospermum & 2 & 7 \\
\hline 梧桐科 Sterculiaceae & 苹波属 Sterculia & 2 & 2 \\
\hline 梧桐科 Sterculiaceae & 蛇婆子属 Waltheria & 2 & 2 \\
\hline 安息香科 Styracaceae & 安息香属 Styrax & 3 & 3 \\
\hline 山矾科 Symplocaceae & 山矾属 Symplocos & 2 & 2 \\
\hline 山茶科 Theaceae & 山茶属 Camellia & 2 & 7 \\
\hline 山茶科 Theaceae & 柃木属 Eurya & 2 & 3 \\
\hline 山茶科 Theaceae & 木荷属 Schima & 2 & 7 \\
\hline 瑞香科 Thymelaeaceae & 沉香属 Aquilaria & 1 & 7 \\
\hline 瑞香科 Thymelaeaceae & 瑞香属 Daphne & 1 & 8 \\
\hline 瑞香科 Thymelaeaceae & 狼毒属 Stellera & 1 & 11 \\
\hline 瑞香科 Thymelaeaceae & 荛花属 Wikstroemia & 1 & 5 \\
\hline 椴树科 Tiliaceae & 一担柴属 Colona & 2 & 7 \\
\hline 椴树科 Tiliaceae & 田麻属 Corchoropsis & 2 & $14(\mathrm{SJ})$ \\
\hline 椴树科 Tiliaceae & 黄麻属 Corchorus & 2 & 2 \\
\hline 椴树科 Tiliaceae & 滇桐属 Craigia & 2 & 7 \\
\hline 椴树科 Tiliaceae & 扁担杆属 Grewia & 2 & 4 \\
\hline 椴树科 Tiliaceae & 刺蒴麻属 Triumfetta & 2 & 2 \\
\hline 榆科 Ulmaceae & 朴属 Celtis & 1 & 2 \\
\hline 榆科 Ulmaceae & 山黄麻属 Trema & 1 & 2 \\
\hline 榆科 Ulmaceae & 榆属 Ulmus & 1 & 8 \\
\hline 榆科 Ulmaceae & 榉属 Zelkova & 1 & 10 \\
\hline 伞形科 Umbelliferae & 当归属 Angelica & 1 & 8 \\
\hline 企形科 Umbelliferae & 芹属 Apium & 1 & 1 \\
\hline 伞形科 Umbelliferae & 柴胡属 Bupleurum & 1 & 8 \\
\hline 伞形科 Umbelliferae & 葛缕子属 Carum & 1 & 8 \\
\hline 伞形科 Umbelliferae & 积雪草属 Centella & 1 & 1 \\
\hline 伞形科 Umbelliferae & 蛇床属 Cnidium & 1 & 9 \\
\hline 伞形科 Umbelliferae & 芫荌属 Coriandrum & 1 & 12 \\
\hline 企形科 Umbelliferae & 鸭儿芹属 Cryptotaenia & 1 & 8 \\
\hline 伞形科 Umbelliferae & 胡萝卜属 Daucus & 1 & 8 \\
\hline 伞形科 Umbelliferae & 茴香属 Foeniculum & 1 & 12 \\
\hline 伞形科 Umbelliferae & 独活属 Heracleum & 1 & 8 \\
\hline 伞形科 Umbelliferae & 天胡荌属 Hydrocotyle & 1 & 2 \\
\hline 伞形科 Umbelliferae & 菜本属 Ligusticum & 1 & 8 \\
\hline 伞形科 Umbelliferae & 水芹属 Oenanthe & 1 & 8 \\
\hline 伞形科 Umbelliferae & 香根芹属 Osmorhiza & 1 & 9 \\
\hline 伞形科 Umbelliferae & 欧芹属 Petroselinum & 1 & 12 \\
\hline 伞形科 Umbelliferae & 前胡属 Peucedanum & 1 & 10 \\
\hline 伞形科 Umbelliferae & 茴芹属 Pimpinella & 1 & 8 \\
\hline
\end{tabular}




\begin{tabular}{|c|c|c|c|}
\hline 科 Family & 属 Genus & $\begin{array}{l}\text { 科分布区类型 } \\
\text { Family area types }\end{array}$ & $\begin{array}{l}\text { 属分布区类型 } \\
\text { Genus area types }\end{array}$ \\
\hline 伞形科 Umbelliferae & 囊瓣芹属 Pternopetalum & 1 & 14 \\
\hline 伞形科 Umbelliferae & 变豆菜属 Sanicula & 1 & 1 \\
\hline 伞形科 Umbelliferae & 防风属 Saposhnikovia & 1 & 11 \\
\hline 伞形科 Umbelliferae & 西风芹属 Seseli & 1 & 10 \\
\hline 伞形科 Umbelliferae & 泽芹属 Sium & 1 & 1 \\
\hline 伞形科 Umbelliferae & 窃衣属 Torilis & 1 & 10 \\
\hline 伞形科 Umbelliferae & 䊁果芹属 Trachyspermum & 1 & 6 \\
\hline 荨麻科 Urticaceae & 亖麻属 Boehmeria & 2 & 2 \\
\hline 菷麻科 Urticaceae & 微柱麻属 Chamabainia & 2 & 7 \\
\hline 菷麻科 Urticaceae & 水麻属 Debregeasia & 2 & 6 \\
\hline 蕁麻科 Urticaceae & 火麻树属 Dendrocnide & 2 & 5 \\
\hline 荨麻科 Urticaceae & 单芯麻属 Droguetia & 2 & 6 \\
\hline 菖麻科 Urticaceae & 楼梯草属 Elatostema & 2 & 4 \\
\hline 莳麻科 Urticaceae & 蝎子草属 Girardinia & 2 & 6 \\
\hline 菷麻科 Urticaceae & 糯米团属 Gonostegia & 2 & 5 \\
\hline 蕁麻科 Urticaceae & 艾麻属 Laportea & 2 & 2 \\
\hline 寽麻科 Urticaceae & 水丝麻属 Maoutia & 2 & 7 \\
\hline 莳麻科 Urticaceae & 紫麻属 Oreocnide & 2 & 7 \\
\hline 菖麻科 Urticaceae & 冷水花属 Pilea & 2 & 2 \\
\hline 寽麻科 Urticaceae & 雾水葛属 Pouzolzia & 2 & 2 \\
\hline 菷麻科 Urticaceae & 荨麻属 Urtica & 2 & 1 \\
\hline 败酱科 Valerianaceae & 败酱属 Patrinia & 1 & 10 \\
\hline 败酱科 Valerianaceae & 缴草属 Valeriana & 1 & 8 \\
\hline 马鞭草科 Verbenaceae & 紫珠属 Callicarpa & 3 & 2 \\
\hline 马鞭草科 Verbenaceae & 莸属 Caryopteris & 3 & 14 \\
\hline 马鞭草科 Verbenaceae & 大青属 Clerodendrum & 3 & 2 \\
\hline 马鞭草科 Verbenaceae & 假连尧属 Duranta & 3 & 3 \\
\hline 马鞭草科 Verbenaceae & 马缨丹属 Lantana & 3 & 2 \\
\hline 马鞭草科 Verbenaceae & 过江藤属 Phyla & 3 & 3 \\
\hline 马鞭草科 Verbenaceae & 豆腐柴属 Premna & 3 & 4 \\
\hline 马鞭草科 Verbenaceae & 千解草属 Pygmaeopremna & 3 & 5 \\
\hline 马鞭草科 Verbenaceae & 马鞭草属 Verbena & 3 & 2 \\
\hline 马鞭草科 Verbenaceae & 牡荆属 Vitex & 3 & 2 \\
\hline 堇菜科 Violaceae & 堇菜属 Viola & 1 & 1 \\
\hline 檞寄生科 Viscaceae & 檞寄生属 Viscum & 1 & 4 \\
\hline 葡萄科 Vitaceae & 蛇葡萄属 Ampelopsis & 2 & 9 \\
\hline 葡萄科 Vitaceae & 乌蔹莓属 Cayratia & 2 & 4 \\
\hline 葡萄科 Vitaceae & 白粉藤属 Cissus & 2 & 2 \\
\hline 葡萄科 Vitaceae & 地锦属 Parthenocissus & 2 & 9 \\
\hline 葡萄科 Vitaceae & 崖爬藤属 Tetrastigma & 2 & 5 \\
\hline 葡萄科 Vitaceae & 葡萄属 Vitis & 2 & 8 \\
\hline
\end{tabular}




\begin{tabular}{|c|c|c|c|}
\hline 科 Family & 属 Genus & $\begin{array}{l}\text { 科分布区类型 } \\
\text { Family area types }\end{array}$ & $\begin{array}{l}\text { 属分布区类型 } \\
\text { Genus area types }\end{array}$ \\
\hline 姜科 Zingiberaceae & 山姜属 Alpinia & 5 & 5 \\
\hline 姜科 Zingiberaceae & 豆冦属 Amomum & 5 & 5 \\
\hline 姜科 Zingiberaceae & 大苍姜属 Caulokaempferia & 5 & 7 \\
\hline 姜科 Zingiberaceae & 舞花姜属 Globba & 5 & 5 \\
\hline 姜科 Zingiberaceae & 姜花属 Hedychium & 5 & 6 \\
\hline 姜科 Zingiberaceae & 姜属 Zingiber & 5 & 5 \\
\hline 䒨揫科 Zygophyllaceae & 苼藜属 Tribulus & 2 & 2 \\
\hline 铁线溦科 Adiantaceae & 铁线蕨属 Adiantum & 1 & 1 \\
\hline 书带濒科 Antrophyaceae & 书带蒴属 Vittaria & 2 & 2 \\
\hline 叉濒科 Aspidiaceae & 叉蒴属 Tectaria & 2 & $14(\mathrm{SH})$ \\
\hline 铁角䔊科 Aspleniaceae & 铁角蒝属 Asplenium & 1 & 1 \\
\hline 铁角硕科 Aspleniaceae & 水鳖硕属 Sinephropteris & 1 & $14(\mathrm{SH})$ \\
\hline 蹄盖䝫科 Athyriaceae & 短肠薜属 Allantodia & 1 & 2 \\
\hline 蹄盖媭科 Athyriaceae & 蹄盖濒属 Athyrium & 1 & 1 \\
\hline 蹄盖偋科 Athyriaceae & 假冷蒴属 Pseudocystopteris & 1 & 11 \\
\hline 乌毛蕨科 Blechnaceae & 狗脊属 Woodwardia & 2 & 1 \\
\hline 桫椤科 Cyatheaceae & 杪椤属 Alsophila & 2 & 2 \\
\hline 骨碎补科 Davalliaceae & 阴石鄀属 Humata & 7 & 4 \\
\hline 姬锁科 Dennstaedtiaceae & 碗蕨属 Dennstaedtia & 2 & 2 \\
\hline 姬䕬科 Dennstaedtiaceae & 鳞盖嵚属 Microlepia & 2 & 4 \\
\hline 葪蕨科 Drynariaceae & 葪鄀属 Drynaria & 5 & 5 \\
\hline 鳞毛葓科 Dryopteridaceae & 复叶耳蒴属 Arachniodes & 1 & 2 \\
\hline 鳞毛蕨科 Dryopteridaceae & 贯众属 Cyrtomium & 1 & 6 \\
\hline 鳞毛蕨科 Dryopteridaceae & 鳞毛蕨属 Dryopteris & 1 & 1 \\
\hline 鳞毛蕨科 Dryopteridaceae & 耳鄀属 Polystichum & 1 & 1 \\
\hline 木贼科 Equisetaceae & 木贼属 Equisetum & 1 & 1 \\
\hline 里白科 Gleicheniaceae & 芒萁属 Dicranopteris & 2 & 4 \\
\hline 里白科 Gleicheniaceae & 里白属 Hicriopteris & 2 & 2 \\
\hline 裸子蕨科 Hemionitidaceae & 凤Y蕨属 Coniogramme & 2 & 2 \\
\hline 裸子蔚科 Hemionitidaceae & 金毛裸蕨属 Gymnopteris & 2 & 10 \\
\hline 肿足硕科 Hypodematiaceae & 肿足蕨属 Hypodematium & 6 & 6 \\
\hline 陵齿荻科 Lindsaeaceae & 陵齿硕属 Lindsaea & 2 & 2 \\
\hline 陵齿硕科 Lindsaeaceae & 乌蕨属 Stenoloma & 2 & 2 \\
\hline 海金沙科 Lygodiaceae & 海金沙属 Lygodium & 2 & 2 \\
\hline 苹科 Marsileaceae & 苹属 Marsilea & 1 & 11 \\
\hline 肾蕨科 Nephrolepidaceae & 肾鄀属 Nephrolepis & 2 & 2 \\
\hline 紫萁科 Osmundaceae & 紫萁属 Osmunda & 1 & 8 \\
\hline 瘤足蕨科 Plagiogyriaceae & 瘤足荻属 Plagiogyria & 3 & 2 \\
\hline 水龙骨科 Polypodiaceae & 节肢蕨属 Arthromeris & 1 & $14(\mathrm{SH})$ \\
\hline 水龙骨科 Polypodiaceae & 瓦韦属 Lepisorus & 1 & 6 \\
\hline 水龙骨科 Polypodiaceae & 盾蕨属 Neolepisorus & 1 & 6 \\
\hline
\end{tabular}




\begin{tabular}{|c|c|c|c|}
\hline 科 Family & 属 Genus & $\begin{array}{l}\text { 科分布区类型 } \\
\text { Family area types }\end{array}$ & $\begin{array}{l}\text { 属分布区类型 } \\
\text { Genus area types }\end{array}$ \\
\hline 水龙骨科 Polypodiaceae & 瘤蕨属 Phymatosorus & 1 & 4 \\
\hline 水龙骨科 Polypodiaceae & 水龙骨属 Polypodiodes & 1 & 14 \\
\hline 水龙骨科 Polypodiaceae & 石韦属 Pyrrosia & 1 & 1 \\
\hline 凤尾葓科 Pteridaceae & 凤尾嵚属 Pteris & 2 & 2 \\
\hline 蒝科 Pteridiaceae & 蕨属 Pteridium & 1 & 1 \\
\hline 中国硕科 Sinopteridaceae & 粉背䊏属 Aleuritopteris & 1 & 1 \\
\hline 中国鄀科 Sinopteridaceae & 碎米蕼属 Cheilosoria & 1 & 2 \\
\hline 中国嵚科 Sinopteridaceae & 薄鳞蓀属 Leptolepidium & 1 & 11 \\
\hline 中国烣科 Sinopteridaceae & 金粉蒴属 Onychium & 1 & 2 \\
\hline 中国菜科 Sinopteridaceae & 旱硕属 Pellaea & 1 & 1 \\
\hline 中国硕科 Sinopteridaceae & 中国蕨属 Sinopteris & 1 & 15 \\
\hline 金星蕨科 Thelypteridaceae & 钩毛蕨属 Cyclogramma & 1 & 14 \\
\hline 金星蕨科 Thelypteridaceae & 毛蕨属 Cyclosorus & 1 & 2 \\
\hline 金星蕨科 Thelypteridaceae & 针毛茨属 Macrothelypteris & 1 & 5 \\
\hline 金星媭科 Thelypteridaceae & 金星蒴属 Parathelypteris & 1 & 2 \\
\hline 金星颐科 Thelypteridaceae & 卵果蕨属 Phegopteris & 1 & 8 \\
\hline 金星蕨科 Thelypteridaceae & 新月䕬属 Pronephrium & 1 & 7 \\
\hline 金星蒴科 Thelypteridaceae & 假毛藓属 Pseudocyclosorus & 1 & 2 \\
\hline 金星蕨科 Thelypteridaceae & 溪边鄀属 Stegnogramma & 1 & 2 \\
\hline 柏科 Cupressaceae & 柏木属 Cupressus & 8 & 8 \\
\hline 柏科 Cupressaceae & 侧柏属 Platycladus & 8 & $14(\mathrm{SH})$ \\
\hline 柏科 Cupressaceae & 圆柏属 Sabina & 8 & 8 \\
\hline 苏铁科 Cycadaceae & 苏铁属 Cycas & 5 & 5 \\
\hline 松科 Pinaceae & 冷杉属 Abies & 8 & 8 \\
\hline 松科 Pinaceae & 雪松属 Cedrus & 8 & 10 \\
\hline 松科 Pinaceae & 油杉属 Keteleeria & 8 & $14(\mathrm{SH})$ \\
\hline 松科 Pinaceae & 落叶松属 Larix & 8 & 8 \\
\hline 松科 Pinaceae & 云杉属 Picea & 8 & 8 \\
\hline 松科 Pinaceae & 松属 Pinus & 8 & 8 \\
\hline 杉科 Taxodiaceae & 柳杉属 Cryptomeria & 8 & $14(\mathrm{SJ})$ \\
\hline 杉科 Taxodiaceae & 水松属 Glyptostrobus & 8 & 15 \\
\hline 石杉科 Huperziaceae & 石杉属 Huperzia & 1 & 1 \\
\hline 石松科 Lycopodiaceae & 石松属 Lycopodium & 1 & 1 \\
\hline 卷柏科 Selaginellaceae & 卷柏属 Selaginella & 1 & 1 \\
\hline
\end{tabular}

